\title{
In vitro cytotoxicity and catalytic evaluation of dioxidovanadium(v) complexes in an azohydrazone ligand environment $\uparrow$
}

\author{
Monalisa Mohanty, ${ }^{a}$ Shailendra K. Maurya, ${ }^{b}$ Atanu Banerjee, ${ }^{a}$ \\ Sushree Aradhana Patra, ${ }^{a}$ Mannar R. Maurya, (iD b ${ }^{b}$ Aurélien Crochet, (iD c \\ Krzysztof Brzezinski iD and Rupam Dinda iD *a
}

\begin{abstract}
Three new anionic dioxidovanadium( $\mathrm{V})$ complexes $\left(\mathrm{HNEt}_{3}\right)\left[\mathrm{VO}_{2}(\mathrm{~L})^{1-3}\right](\mathbf{1 - 3})$ of tridentate binegative aroylhydrazone ligands containing the azobenzene moiety were synthesized and structurally characterized. The aroylhydrazone ligands $\left(\mathrm{H}_{2} \mathrm{~L}^{1-3}\right)$ were derived from the condensation of 5-(arylazo) salicylaldehyde derivatives with the corresponding aroyl hydrazides. All the synthesized ligands and metal complexes were successfully characterized by several physicochemical techniques, namely, elemental analysis, electrospray ionization mass spectrometry, spectroscopic methods (IR, UV-vis and NMR), and cyclic voltammetry. Single-crystal X-ray diffraction crystallography of 1-3 revealed five-coordinate geometry, where the ligand coordinates to the metal centre in a binegative tridentate $\mathrm{O}, \mathrm{N}, \mathrm{O}$ coordinating anion and two oxido-O atoms, resulting in distortion towards the square pyramidal structure. The complexes were further evaluated for their in vitro cytotoxicity against HeLa and HT-29 cancer cell lines. All the complexes manifested a cytotoxic potential that was found to be comparable with that of clinically referred drugs, while complex 3 proved to be the most cytotoxic among the three complexes for both cell lines, which may be due to the synergistic effect of the naphthyl substituent in the azohydrazone ligand environment coordinated to the vanadium metal. The synthesized complexes 1-3 were probed as catalysts for the oxidative bromination of thymol and styrene as a functional mimic of vanadium haloperoxidases (VHPOs). All the reactions provided high percentages of conversion (>90\%) with a high turnover frequency (TOF) in the presence of the catalysts 1-3. In particular, for the oxidative bromination of thymol, the percentage of conversion and TOF were in the ranges of $98-99 \%$ and $5380-7173\left(\mathrm{~h}^{-1}\right)$, respectively. Besides, 3 bearing the naphthyl substituent showed the highest TOF among all the complexes for the oxidative bromination of both thymol and styrene.
\end{abstract}

\section{Introduction}

Paramount interest has been given to the coordination chemistry of vanadium complexes due to their significance in various biochemical, pharmacological, and catalytic activities. ${ }^{1}$ As vanadium

\footnotetext{
${ }^{a}$ Department of Chemistry, National Institute of Technology, Rourkela, 769008 Odisha, India. E-mail: rupamdinda.nitrkl@gmail.com, rupamdinda@nitrkl.ac.in

${ }^{b}$ Department of Chemistry, Indian Institute of Technology Roorkee, Roorkee 247667, India

${ }^{c}$ Department of Chemistry, Fribourg Center for Nanomaterials, University of Fribourg, CH-1700 Fribourg, Switzerland

${ }^{d}$ Institute of Chemistry, University of Bialystok, Ciolkowskiego $1 \mathrm{~K}, 15-245$, Bialystok, Poland

$\dagger$ Electronic supplementary information (ESI) available. CCDC 1903090 (1), 1903091 (2) and 1902693 (3). For ESI and crystallographic data in CIF or other electronic format see DOI: $10.1039 / \mathrm{c} 9 \mathrm{nj} 01815 \mathrm{~h}$
}

metal possesses the ability to assume various oxidation states of $3+$, $4+$ and $5+$, it shows diverse biological roles and interacts with different biomolecules. ${ }^{2}$ For instance, various marine as well as terrestrial organisms utilize vanadium for their life processes; ${ }^{3}$ vanadium haloperoxidase (V-HPOs) found in marine algae can facilitate the oxidative halogenation of aromatic organic complexes in the presence of organic hydroperoxides, hydrogen peroxide or molecular oxygen. ${ }^{4}$ It also plays a vital role in enzymes, such as vanadium-dependent nitrogenases, nitrate reductases and amavadin. $^{5,6}$ Furthermore, the pharmacological potential of vanadium complexes has been successfully shown in the treatment of type I and type II diabetes, while in the past decade, they have also been studied as anti-tumor agents. ${ }^{7}$

In this context, vanadium complexes have exhibited promising cytotoxicity against a wide spectrum of human cancer cell lines. ${ }^{7}$ These metal complexes have shown reduced side effects, more potent action, better selectivity and higher cytotoxicity in 
both in vitro and in vivo models. ${ }^{1 b, 8}$ Besides, a vanadium complex, i.e., Metvan can induce apoptosis in testicular and ovarian tumors. ${ }^{9}$ Vanadium complexes demonstrate apoptosis-inducing ability along with higher cytotoxicity in comparison to free ligands. ${ }^{10}$ As the pharmacological properties of metal complexes are a result of both the metal centre and the ligand backbone, it is highly beneficial to employ bioactive ligands in the design of metal-based drugs. Such ligands include aroylhydrazones $-\mathrm{NH}-\mathrm{N}=\mathrm{CRR}^{\prime}\left(\mathrm{R}\right.$ and $\mathrm{R}^{\prime}=\mathrm{H}$, alkyl, aryl); they are known to manifest a wide variety of properties such as antimicrobial and antitumor activities and therefore represent an important class of compounds with profound applications in chemistry and medicine. ${ }^{11}$ In addition, the use of the azobenzene moiety in the ligand backbone is of considerable interest because it exhibits interesting biological properties. As DNA is the primary intracellular target of any anti-cancer drug, these azobenzene derivatives, which usually exist in their stable trans-isomer form, are known to interact with DNA through the base-stacking method. ${ }^{12}$ Furthermore, the higher substitution and planarity of ligands such as benzyl and naphthyl groups can also lead to an enhanced DNA interaction. ${ }^{13}$

The capability of vanadium to easily interconvert between various oxidation states, its high affinity for oxygen and also its Lewis acidic nature make vanadium appropriate and relevant for applications in redox and Lewis acid-catalyzed reactions. ${ }^{14}$ Consequently, vanadium has been widely used in the catalytic oxidation reactions of various organic substrates including sulphoxidation, ${ }^{15}$ bromination, ${ }^{16}$ oxidation of alcohols,${ }^{17}$ epoxidation of olefins, ${ }^{18}$ and hydroxylation of aromatic hydrocarbons. ${ }^{19}$ Moreover, the combination of vanadium metal with aroylhydrazone ligands is a good choice for catalytic oxidation because of the latter's ability to resist oxidation. ${ }^{20}$ Therefore, the use of low-cost, environmental friendly vanadium aroylhydrazone complexes, which can also alleviate the oxidizing nature of the oxidants, ${ }^{21}$ affording new-generation catalysts with a high turnover number (TON), selectivity and sustainability, is the need of the hour.

As a part of our ongoing research on the oxidovanadium(v) metal complexes of aroylazines in relation to their biological ${ }^{10 a-c}$ and catalytic applications ${ }^{22 a}$ and some non-oxido vanadium(Iv) complexes, which are very stable in solid as well as in the solution state, ${ }^{22 b}$ in the present work, we reported the synthesis of three new dioxidovanadium(v) complexes $\left(\mathrm{HNEt}_{3}\right)\left[\mathrm{VO}_{2}(\mathrm{~L})^{1-3}\right](1-3)$ of tridentate binegative aroylhydrazone ligands containing the azobenzene moiety $\mathbf{H}_{2} \mathbf{L}^{1-3}$. Also, it would be relevant to mention here that hydrogen bonding interactions for the design and synthesis of extended frameworks via supramolecular interactions have been on the forefront of research, especially in the fields of molecular recognition and engineering of molecular solids. ${ }^{23}$ In this study, we used triethylamine as a source of counterions for the formation of polymeric aggregates. These counterions play a pivotal role, increasing the stability of the components of the supramolecular interactions through hydrogen bonding networks by charge neutralization. Furthermore, these complexes also exhibited enhanced water solubility, making them important subjects for biological and catalytic studies. All the synthesized ligands and metal complexes were successfully characterized by elemental analysis as well as through various spectroscopic techniques (IR, UV-vis and NMR).
Considering the above-discussed biological and catalytic relevance of vanadium complexes containing $\mathrm{O}, \mathrm{N}$ donor ligands, we studied the complexes for their antiproliferative efficacy against human cervical cancer (HeLa) and human colorectal adenocarcinoma (HT-29) cell lines and also for their catalytic potential in the oxidative bromination of thymol and styrene as a functional mimic of vanadium haloperoxidases (VHPOs).

\section{Experimental section}

\section{General materials and methods}

All the chemicals were procured commercially and were used in their original form. $\mathrm{VO}(\mathrm{acac})_{2}$ was prepared as described in the literature. ${ }^{24}$ Reagent-grade solvents were dried and distilled prior to use. HeLa and HT-29 cell lines were obtained from the National Centre of Cell Science (NCCS), Pune, India. Dulbecco's modified Eagle medium (DMEM), Dulbecco's phosphate buffered saline (DPBS), trypsin EDTA solution, fetal bovine serum (FBS), and antibiotic-antimitotic solution were procured from Himedia, Mumbai, India. MTT (3-[4,5-dimethylthiazol-2-yl]-2,5-diphenyltetrazolium) and DAPI (4',6-diamidino-2-phenylindole dihydrochloride) were purchased from Sigma-Aldrich, India. Elemental analyses were performed on a Vario ELcube CHNS Elemental Analyzer. IR spectra were recorded on a PerkinElmer Spectrum RXI spectrometer. ${ }^{1} \mathrm{H}$ and ${ }^{13} \mathrm{C}$ NMR spectra were studied with a Bruker Ultrashield $400 \mathrm{MHz}$ spectrometer using $\mathrm{SiMe}_{4}$ as an internal standard, and ${ }^{51} \mathrm{~V}$ was studied using $\mathrm{VOCl}_{3}$ as an internal standard. Electronic spectra were examined on a Lamda25, PerkinElmer spectrophotometer. Electrochemical data were collected using a PAR electrochemical analyser and a PC-controlled potentiostat/galvanostat (PAR 273A) at $298 \mathrm{~K}$ in a dry nitrogen atmosphere. Cyclic voltammetry experiments were carried out with a platinum working electrode, a platinum auxiliary electrode and an SCE reference electrode. Commercially available TBAP (tetrabutyl ammonium perchlorate) was dried and used as a supporting electrolyte for recording the cyclic voltammograms of the complexes. ESI-MS of the complexes was conducted on a Bruker MAT SSQ 710 spectrometer, employing a complex concentration of $100 \mathrm{pmol} \mu \mathrm{L}^{-1}$. A Shimadzu 2010 plus gas-chromatograph fitted with an Rtx-1 capillary column $(30 \mathrm{~m} \times 0.25 \mathrm{~mm} \times 0.25 \mu \mathrm{m})$ and a flame ionization detector (FID) were utilized to analyse the reaction products. The quantification of the products was made on the basis of the relative peak area of the respective product. The identification of these products was performed using a GC-MS model PerkinElmer, Clarus 500 and the fragments of each product were compared with the available library. The percent conversion of the substrate and the selectivity of the products were calculated from the GC data using the following formulae:

\section{\%Conversion of substrate}

$$
=100-\frac{\text { Peak area of a substrate }}{\text { Total area of a substrate }+ \text { products }} \times 100
$$

$\%$ Selectivity of a product $=\frac{\text { Peak area of a product }}{\text { Total area of products }} \times 100$ 
Caution: Although no problems were encountered during the course of this work, attention must be drawn to the potentially explosive nature of perchlorates.

\section{Synthesis of ligands $\left[\mathrm{H}_{2} \mathrm{~L}^{1-3}\right]$}

First, 5-(arylazo) salicylaldehyde containing the azobenzene moiety was prepared, as reported in the literature. ${ }^{25}$ The ligands $\left[\mathbf{H}_{2} \mathbf{L}^{\mathbf{1 - 3}}\right]$ were then synthesized by condensing 5-(arylazo) salicylaldehyde with their corresponding aroyl hydrazides (benzoic hydrazide) $\left(\mathbf{H}_{2} \mathbf{L}^{\mathbf{1}}\right)$, salicyclic hydrazide $\left(\mathbf{H}_{2} \mathbf{L}^{\mathbf{1}}\right)$ and 3-hydroxy-2naphthoic hydrazide $\left(\mathbf{H}_{2} \mathbf{L}^{\mathbf{1}}\right)$ at a 1:1 molar ratio in an ethanolic medium. The resulting light orange product was filtered, washed and dried over fused $\mathrm{CaCl}_{2}$.

$\mathbf{H}_{2} \mathbf{L}^{1}$ : Yield: $0.24 \mathrm{~g}(72 \%)$. Anal. calcd for $\mathrm{C}_{20} \mathrm{H}_{16} \mathrm{~N}_{4} \mathrm{O}_{2}$ : C, 69.76; H, 4.68; N, 16.27. Found: C, 69.54; H, 4.59; N, $16.10 \%$. FTIR $\left(\mathrm{KBr}, \nu_{\max } / \mathrm{cm}^{-1}\right): \nu(\mathrm{O}-\mathrm{H}) 3412, \nu(\mathrm{N}-\mathrm{H}) 3056, \nu(\mathrm{C}=\mathrm{O})$ 1675, $\nu(\mathrm{C}=\mathrm{N}) 1612, \nu(\mathrm{N}=\mathrm{N}) 1494 .{ }^{1} \mathrm{H}$ NMR $(400 \mathrm{MHz}$, DMSO-d $\left.\mathrm{d}_{6}\right): \delta(\mathrm{ppm})=12.23(\mathrm{~s}, 1 \mathrm{H},-\mathrm{OH}), 11.83(\mathrm{~s}, 1 \mathrm{H},-\mathrm{NH})$, $8.78(\mathrm{~s}, 1 \mathrm{H},-\mathrm{CH}), 8.25-7.13\left(\mathrm{~m}, 13 \mathrm{H}\right.$, aromatic). ${ }^{13} \mathrm{C}$ NMR $(100$ MHz, DMSO- $\left.\mathrm{d}_{6}\right): \delta(\mathrm{ppm})=168.49,164.67,152.48,146.82$ 145.60, 133.26, 132.50, 131.35, 129.87, 129.03, 128.16, 126.30, 123.84, 122.75, 120.26, 117.78 .

$\mathrm{H}_{2} \mathbf{L}^{2}$ : Yield: $0.28 \mathrm{~g}$ (71\%). Anal. calcd for $\mathrm{C}_{20} \mathrm{H}_{16} \mathrm{~N}_{4} \mathrm{O}_{3}$ : C, 66.66; H, 4.48; N, 15.55. Found: C, 66.88; H, 4.89; N, $15.05 \%$. FTIR $\left(\mathrm{KBr}, \nu_{\max } / \mathrm{cm}^{-1}\right): \nu(\mathrm{O}-\mathrm{H}) 3202, \nu(\mathrm{N}-\mathrm{H}) 3059, \nu(\mathrm{C}=\mathrm{O})$ 1644, $\nu(\mathrm{C}=\mathrm{N})$ 1607, $\nu(\mathrm{N}=\mathrm{N})$ 1493. ${ }^{1} \mathrm{H}$ NMR $(400 \mathrm{MHz}$, DMSO- $\left.\mathrm{d}_{6}\right): \delta(\mathrm{ppm})=12.10(\mathrm{~s}, 1 \mathrm{H},-\mathrm{OH}), 11.88(\mathrm{~s}, 1 \mathrm{H}$, phenolic OH) $11.82(\mathrm{~s}, 1 \mathrm{H},-\mathrm{NH}), 8.8(\mathrm{~s}, 1 \mathrm{H},-\mathrm{CH}), 8.2-6.9(\mathrm{~m}, 12 \mathrm{H}$, aromatic). ${ }^{13} \mathrm{C}$ NMR (100 MHz, DMSO-d $\left.{ }_{6}\right): \delta(\mathrm{ppm})=163.55$, 160.58, 153.64, 150.89, 148.71, 146.99, 146.49, 145.36, 141.78, $130.37,128.78,126.45,123.91,122.57,121.33,118.72,114.81$, 112.87 .

$\mathbf{H}_{2} \mathbf{L}^{3}$ : Yield: $0.26 \mathrm{~g}$ (69\%). Anal. calcd for $\mathrm{C}_{24} \mathrm{H}_{18} \mathrm{~N}_{4} \mathrm{O}_{3}$ : C, 70.23; H, 4.42; N, 13.65. Found: C, 70.68; H, 4.47; N, 13.75\%. FTIR $\left(\mathrm{KBr}, \nu_{\max } / \mathrm{cm}^{-1}\right): \nu(\mathrm{O}-\mathrm{H}) 3161, \nu(\mathrm{N}-\mathrm{H}) 3056, \nu(\mathrm{C}=\mathrm{O})$ 1633, $\nu(\mathrm{C}=\mathrm{N}) 1625, \nu(\mathrm{N}=\mathrm{N})$ 1522. ${ }^{1} \mathrm{H}$ NMR $(400 \mathrm{MHz}$, DMSO- $\left.\mathrm{d}_{6}\right): \delta(\mathrm{ppm})=12.13(\mathrm{~s}, 1 \mathrm{H},-\mathrm{OH}), 12.01(\mathrm{~s}, 1 \mathrm{H}$, naphthoic $\mathrm{OH}), 11.82(\mathrm{~s}, 1 \mathrm{H},-\mathrm{NH}), 8.81(\mathrm{~s}, 1 \mathrm{H},-\mathrm{CH}), 8.48-7.15(\mathrm{~m}, 14 \mathrm{H}$, aromatic). ${ }^{13} \mathrm{C}$ NMR (100 MHz, DMSO-d $\left.\mathrm{d}_{6}\right): \delta(\mathrm{ppm})=164.23$, 160.71, 154.47, 152.47, 147.27, 145.59, 136.37, 131.40, 130.79, $129.90,129.15,128.78,127.24,126.34,124.31,123.53,122.76$, $122.64,120.65,120.23,117.80,111.03$.

\section{Synthesis of dioxidovanadium(v) complexes $\left(\mathrm{HNEt}_{3}\right)\left[\mathrm{VO}_{2}(\mathrm{~L})^{1-3}\right]$} (1-3)

The $\left(\mathrm{HNEt}_{3}\right)\left[\mathrm{VO}_{2}(\mathrm{~L})^{1-3}\right]$ (1-3) complexes were synthesized by refluxing the azohydrazone ligands $\left[\mathbf{H}_{2} \mathbf{L}^{\mathbf{1 - 3}}\right]$ and $\left[\mathrm{VO}(\mathrm{acac})_{2}\right]$ in an alcohol medium using triethylamine as a base for $3 \mathrm{~h}$. Dark brown crystals, suitable for X-ray analysis, were obtained from the filtrate after 2-4 days.

$\left(\mathrm{HNEt}_{3}\right)\left[\mathrm{VO}_{2}(\mathrm{~L})^{\mathbf{1}}\right]$ (1). Yield: $0.28 \mathrm{~g}(52 \%)$. Anal. calcd for $\mathrm{C}_{31} \mathrm{H}_{44} \mathrm{~N}_{5} \mathrm{O}_{4} \mathrm{~V}$ : C, 61.88; H, 7.37; N, 11.64. Found: C: 61.72; H: 7.90; N: $11.47 \%$. FTIR $\left(\mathrm{KBr}, \nu_{\max } / \mathrm{cm}^{-1}\right): \nu(\mathrm{C}=\mathrm{N}) 1614, \nu(\mathrm{N}=\mathrm{N})$ 1463, $\nu(\mathrm{V}=\mathrm{O})$ 942, 954. UV-vis (DMSO): $\lambda_{\max }, \mathrm{nm}\left(\varepsilon, \mathrm{mol}^{-1} \mathrm{~cm}^{-1}\right)$ : 396(8933), 344(10 600), 261(6133). ${ }^{1} \mathrm{H}$ NMR (400 MHz, DMSO-d $\mathrm{d}_{6}$ ): $\delta(\mathrm{ppm})=9.20(\mathrm{~s}, 1 \mathrm{H},-\mathrm{CH}), 8.91-6.94(\mathrm{~m}, 13 \mathrm{H}$, aromatic $)$, $3.08\left(\mathrm{~m}, 6 \mathrm{H},-\mathrm{CH}_{2}\right), 1.16\left(\mathrm{t}, 9 \mathrm{H},-\mathrm{CH}_{3}\right) .{ }^{13} \mathrm{C} \mathrm{NMR}(100 \mathrm{MHz}$, DMSO- $\left._{6}\right): \delta(\mathrm{ppm})=170.55,168.58,152.46,146.71,146.62$, 146.49, 145.56, 131.37, 129.88, 126.54, 123.29, 122.75, 120.41, $117.72,115.81,112.67,46.27,9.22 .{ }^{51} \mathrm{~V}$ NMR (105 MHz, DMSO$\left.\mathrm{d}_{6}, \mathrm{ppm}\right): \delta=-529$. ESI-MS: $\left(\mathrm{CH}_{3} \mathrm{OH}\right.$; negative ion mode): $\mathrm{m} / \mathrm{z}$ $425.1\left[\mathrm{M}-\left(\mathrm{Et}_{3} \mathrm{NH}\right)^{+}\right]^{+}$.

$\left(\mathrm{HNEt}_{3}\right)\left[\mathrm{VO}_{2}(\mathbf{L})^{2}\right]$ (2). Yield: $0.34 \mathrm{~g}(55 \%)$. Anal. calcd for $\mathrm{C}_{31} \mathrm{H}_{44} \mathrm{~N}_{5} \mathrm{O}_{4} \mathrm{~V}$ : C, 61.88; H, 7.37; N, 11.64. Found: C: 61.01; H: 7.70; N: $11.10 \%$. FTIR (KBr, $\left.\nu_{\max } / \mathrm{cm}^{-1}\right): \nu(\mathrm{O}-\mathrm{H}) 3550, \nu(\mathrm{C}=\mathrm{N})$ $1607, \nu(\mathrm{N}=\mathrm{N}) 1479, \nu(\mathrm{V}=\mathrm{O}) 947,960 . \mathrm{UV}-\mathrm{Vis}(\mathrm{DMSO}): \lambda_{\max }, \mathrm{nm}$ $\left(\varepsilon, \mathrm{mol}^{-1} \mathrm{~cm}^{-1}\right): 395(8405), 346(10328), 265(6620) .{ }^{1} \mathrm{H}$ NMR $\left(400 \mathrm{MHz}, \mathrm{DMSO}^{\left.-\mathrm{d}_{6}\right)} \delta(\mathrm{ppm})=12.15(\mathrm{~s}, 1 \mathrm{H}\right.$, phenolic $\mathrm{OH}), 9.31$ (s, 1H, -CH), 9.05-6.98 (m, 12H, aromatic), 3.08 (m, 6H, $\left.-\mathrm{CH}_{2}\right)$, $1.16\left(\mathrm{t}, 9 \mathrm{H},-\mathrm{CH}_{3}\right) .{ }^{13} \mathrm{C}$ NMR $\left(100 \mathrm{MHz}, \mathrm{DMSO}_{-} \mathrm{d}_{6}\right): \delta(\mathrm{ppm})=$ $170.99,168.28,159.09,157.00,152.58,143.76,133.40,131.52$, 130.94, 129.86, 129.57, 126.14, 122.59, 121.57, 119.89, 119.28, 117.06, 115.72, 46.22, 9.12. ${ }^{51} \mathrm{~V}$ NMR (105 MHz, DMSO-d 6 , ppm): $\delta=-537$. ESI-MS: $\left(\mathrm{CH}_{3} \mathrm{OH}\right.$; negative ion mode): $\mathrm{m} / \mathrm{z} 441.2$ $\left[\mathrm{M}-\left(\mathrm{Et}_{3} \mathrm{NH}\right)^{+}\right]^{+}(2)$.

$\left(\mathbf{H N E t}_{3}\right)\left[\mathrm{VO}_{2}(\mathbf{L})^{3}\right]$ (3). Yield: $0.31 \mathrm{~g}(57 \%)$. Anal. calcd for $\mathrm{C}_{35} \mathrm{H}_{46} \mathrm{~N}_{5} \mathrm{O}_{5} \mathrm{~V}$ : C, 58.49; H, 6.45; N, 9.75. Found: C: 58.07 ; $\mathrm{H}$ : 6.69; N: 9.86\%. FTIR (KBr, $\left.\nu_{\max } / \mathrm{cm}^{-1}\right): \nu(\mathrm{O}-\mathrm{H}) 3442, \nu(\mathrm{C}=\mathrm{N})$ $1609, \nu(\mathrm{N}=\mathrm{N}) 1469, \nu(\mathrm{V}=\mathrm{O}) 947,959$. UV-Vis (DMSO): $\lambda_{\max }, \mathrm{nm}$ $\left(\varepsilon, \mathrm{mol}^{-1} \mathrm{~cm}^{-1}\right): 390(9027), 342(10756), 263(6135) .{ }^{1} \mathrm{H} \mathrm{NMR}$ $\left(400 \mathrm{MHz}, \mathrm{DMSO}-\mathrm{d}_{6}\right): \delta(\mathrm{ppm})=12.04(\mathrm{~s}, 1 \mathrm{H}$, naphthoic $\mathrm{OH})$, $9.37(\mathrm{~s}, 1 \mathrm{H},-\mathrm{CH}), 8.52-6.98(\mathrm{~m}, 14 \mathrm{H}$, aromatic), $3.08(\mathrm{~m}, 6 \mathrm{H}$, $\left.-\mathrm{CH}_{2}\right), 1.15\left(\mathrm{t}, 9 \mathrm{H},-\mathrm{CH}_{3}\right) .{ }^{13} \mathrm{C}$ NMR $\left(100 \mathrm{MHz}, \mathrm{DMSO}-\mathrm{d}_{6}\right): \delta$ $(\mathrm{ppm})=170.45,168.39,157.72,155.22,152.57,143.81,136.53$, 131.63, 130.97, 129.86, 129.26, 128.48, 127.36, 126.33, 126.28, 123.86, 122.59, 121.64, 119.97, 119.58, 118.18, 110.75, 46.26, 9.15. ${ }^{51} \mathrm{~V}$ NMR (105 MHz, DMSO-d $\mathrm{d}_{6}$, ppm): $\delta=-537$. ESI-MS: $\left(\mathrm{CH}_{3} \mathrm{OH}\right.$; negative ion mode): $m / z 491.1\left[\mathrm{M}-\left(\mathrm{Et}_{3} \mathrm{NH}\right)^{+}\right]^{+}$.

\section{Crystallography}

Single crystals of the complexes (1-3) suitable for X-ray diffraction study were obtained at room temperature via slow evaporation from their ethanol/methanol solutions. Crystals of complex 1-2 were mounted on a loop in oil on a Stoe IPDS2 diffractometer equipped with an Oxford Cryosystem open flow cryostat and an Mo K $\alpha$ radiator $(\lambda) 0.71073 \AA$. The crystals were kept at 298(2) K (1) and at (2) during data collection, while the X-ray diffraction data of complex (3) were collected at 100(2) K on a SuperNova diffractometer (Rigaku) with a CCD detector and $\mathrm{Cu} \mathrm{K} \alpha$ radiation. Crystallographic data and details of refinement of all the complexes are summarized in Table 1 . The structures were solved through Olex $2^{26}$ with the help of the ShelXT ${ }^{27}$ structure solution program using intrinsic phasing and refined with the ShelXL ${ }^{28}$ refinement package using least squares minimisation. All hydrogen atoms were initially located in electron-density difference maps. $\mathrm{C}-\mathrm{H}$ hydrogen atoms were constrained to idealized positions, with $\mathrm{C}-\mathrm{H}=0.95-1.00 \AA$ and with $U_{\text {iso }}(\mathrm{H})=1.5 U_{\text {eq }}(\mathrm{C})$ for methyl hydrogen atoms and $U_{\text {iso }}(\mathrm{H})=1.2 U_{\text {eq }}(\mathrm{C})$ for others. The ammonium and hydroxyl hydrogen atoms were freely refined without any constraints or restraints, while the non-hydrogen atoms were refined anisotropically. PLATON software ${ }^{29}$ was used to validate the crystallographic data. 
Table 1 Crystal data and structure refinement details for 1-3

\begin{tabular}{|c|c|c|c|}
\hline Complex & 1 & 2 & 3 \\
\hline Empirical formula & $\mathrm{C}_{26} \mathrm{H}_{30} \mathrm{~N}_{5} \mathrm{O}_{4} \mathrm{~V}$ & $\mathrm{C}_{26} \mathrm{H}_{30} \mathrm{~N}_{5} \mathrm{O}_{5} \mathrm{~V}$ & $\mathrm{C}_{30} \mathrm{H}_{32} \mathrm{~N}_{5} \mathrm{O}_{5} \mathrm{~V}$ \\
\hline Formula weight & 527.49 & 543.49 & 593.55 \\
\hline Temperature & $298(2) \mathrm{K}$ & $200(2) \mathrm{K}$ & $100 \mathrm{~K}$ \\
\hline Wavelength $[\AA]$ & 0.71073 & 0.71073 & 1.54184 \\
\hline Crystal system & Monoclinic & Monoclinic & triclinic \\
\hline Space group & $P 21$ & $P 21$ & $P \overline{1}$ \\
\hline \multicolumn{4}{|l|}{ Unit cell dimensions } \\
\hline$a[\AA]$ & $6.9776(6)$ & $6.8790(3)$ & $9.1706(2)$ \\
\hline$b[\AA]$ & $8.6271(7)$ & $8.5804(3)$ & $11.5525(2)$ \\
\hline$c[\AA]$ & $22.0397(18)$ & $22.3944(11)$ & $15.4622(3)$ \\
\hline$\alpha\left[{ }^{\circ}\right]$ & 90 & 90 & $109.451(2)$ \\
\hline$\beta\left[{ }^{\circ}\right]$ & $94.002(7)$ & $91.071(4)$ & $93.169(2)$ \\
\hline$\gamma\left[{ }^{\circ}\right]$ & 90 & 90 & $112.197(2)$ \\
\hline Volume $\left[\AA^{3}\right]$ & $1323.48(19)$ & $1321.59(10)$ & $1399.04(5)$ \\
\hline$Z$ & 2 & 2 & 2 \\
\hline Density calculated & $1.324 \mathrm{mg} \mathrm{m}^{-3}$ & $1.366 \mathrm{mg} \mathrm{m}^{-3}$ & $1.409 \mathrm{~g} \mathrm{~cm}^{-3}$ \\
\hline Absorption coefficient $\left[\mathrm{mm}^{-1}\right]$ & 0.415 & 0.420 & 3.37 \\
\hline$F(000)$ & 552 & 568 & 620 \\
\hline Crystal size $\left[\mathrm{mm}^{3}\right]$ & $0.13 \times 0.1 \times 0.05$ & $0.26 \times 0.13 \times 0.07$ & $0.24 \times 0.18 \times 0.07$ \\
\hline Theta range for data collection $\left[{ }^{\circ}\right]$ & 5.072 to 50.428 & 3.638 to 50.362 & 4.4 to 76.4 \\
\hline Reflections collected & 17318 & 16895 & 59124 \\
\hline Independent reflections, $R$ (int) & $4686,0.1554$ & $4671,0.0744$ & 5860 \\
\hline Data completeness $[\%]$ & $98.8 \%$ & $98.9 \%$ & 99.8 \\
\hline Data/restraints/parameters & $4684 / 66 / 294$ & $4671 / 3 / 340$ & $5860 / 0 / 436$ \\
\hline Goodness-of-fit on $F^{2}$ & 0.873 & 1.002 & 1.09 \\
\hline Final $R$ indices $[I>2 \operatorname{sigma}(I)]$ & $R_{1}=0.0499, \mathrm{w} R_{2}=0.0919$ & $R_{1}=0.0643, \mathrm{w} R_{2}=0.1478$ & $R_{1}=0.039, \mathrm{w} R_{2}=0.113$ \\
\hline$R$ indices (all data) & $R_{1}=0.1219, \mathrm{w} R_{2}=0.1165$ & $R_{1}=0.0880, \mathrm{w} R_{2}=0.1608$ & $R_{1}=0.0394, \mathrm{w} R=0.1129$ \\
\hline Absolute structure parameter & $0.01(5)$ & $0.019(17)$ & - \\
\hline Extinction coefficient & $\mathrm{n} / \mathrm{a}$ & $\mathrm{n} / \mathrm{a}$ & $\mathrm{n} / \mathrm{a}$ \\
\hline Largest diff. peak and hole e $\AA^{-3}$ & 0.217 and -0.37 & 1.06 and -0.32 & 0.71 and -0.58 \\
\hline CCDC number & 1903090 & 1903091 & 1902693 \\
\hline
\end{tabular}

\section{Cytotoxic study}

MTT assay. The in vitro cytotoxicity of 1-3 was studied against human cervical cancer (HeLa), colon cancer (HT-29) and non-cancerous human epidermal keratinocyte cells (HaCaT) through an MTT dye reduction assay. Prior to the experiment, the cells were maintained in DMEM media supplemented with $10 \%$ FBS and penicillin-streptomycin solution in a humidified (95\% humidity) $\mathrm{CO}_{2}$ incubator $\left(5 \% \mathrm{CO}_{2}\right)$ at $37{ }^{\circ} \mathrm{C}$ with uniform passages at $70-80 \%$ confluence. For the present study, the cells were harvested by trypsinization and seeded at a concentration of $1 \times 10^{4}$ cells per well into a 96-well plate. After $12 \mathrm{~h}$ of initial seeding, the HeLa and HT-29 cells were subjected to treatment with six different concentrations $\left(100,50,10,7,5,3 \mu \mathrm{g} \mathrm{mL}^{-1}\right)$ of each complex, while the HaCaT cells were subjected to treatment with four different concentrations $\left(100,50,10,5 \mu \mathrm{g} \mathrm{mL}^{-1}\right)$ of each complex. The final working concentration of the complexes was prepared in complete DMEM media. Untreated cells cultured in media alone were taken as the control. Subsequently, after 12, 24 and $48 \mathrm{~h}$, the viability of the cells was tested by MTT assay, and the optical density of these cells was measured at $595 \mathrm{~nm}$ using a microplate reader spectrophotometer. ${ }^{10 a}$ The cytotoxicity of the compounds was checked by measuring the percentage cell viability of the cells with respect to the control. ${ }^{30}$ The experiments were performed four times $(n=4)$, and the data were expressed as mean $\pm \mathrm{SD}$. Single variance ANOVA under $95 \%$ confidence interval was used to evaluate the statistical significance of the data.
Nuclear staining assay. The nuclear morphological change during the cell death of the cells in response to treatment with the complexes (1-3) was studied through the DAPI staining method. ${ }^{31}$ HeLa and HT-29 cells were treated with test compounds at a concentration of $10 \mu \mathrm{g} \mathrm{mL} \mathrm{L}^{-1}$ for $24 \mathrm{~h}$. After treatment, the cells were fixed with $4 \%$ formaldehyde for $15 \mathrm{~min}$, followed by permeabilization with $0.1 \%$ Triton $\mathrm{X}-100$. They were subsequently stained with DAPI for $5 \mathrm{~min}$ at $37{ }^{\circ} \mathrm{C}$ and were washed with PBS. Untreated cells were used as the control. The cells were then examined by confocal microscopy (Leica, SP8).

\section{Catalytic reactions of $\left(\mathrm{HNEt}_{3}\right)\left[\mathrm{VO}_{2}(\mathrm{~L})^{1-3}\right](1-3)$}

Oxidative bromination of thymol. The oxidative bromination of thymol was carried out using complexes 1-3 as the catalyst precursors. As a representative, thymol $(1.5 \mathrm{~g}, 10 \mathrm{mmol})$ was added to an aqueous solution $(20 \mathrm{~mL})$ of $\mathrm{KBr}(1.19 \mathrm{~g}, 10 \mathrm{mmol})$ and $30 \%$ aqueous $\mathrm{H}_{2} \mathrm{O}_{2}(1.13 \mathrm{~g}, 10 \mathrm{mmol})$ in a $50 \mathrm{~mL}$ reaction flask. The catalyst $(0.0005 \mathrm{~g})$ and $70 \% \mathrm{HClO}_{4}(1.43 \mathrm{~g}, 10 \mathrm{mmol})$ were added, and the reaction mixture was stirred at room temperature. In all batches, the experimental conditions (e.g., stirring speed, the size of the magnetic bar and reaction flask) were similarly maintained. After $1 \mathrm{~h}$, the products were extracted in the hexane layer and injected into the GC. The identities of all the products were confirmed by GC-MS.

Oxidative bromination of styrene. Styrene $(1.04 \mathrm{~g}, 10 \mathrm{mmol})$ was added to an aqueous solution $(20 \mathrm{~mL})$ of $\mathrm{KBr}(1.19 \mathrm{~g}$, $10 \mathrm{mmol})$ and $30 \%$ aqueous $\mathrm{H}_{2} \mathrm{O}_{2}(1.13 \mathrm{~g}, 10 \mathrm{mmol})$ in a $50 \mathrm{~mL}$ 
reaction flask. The catalyst $(0.0005 \mathrm{~g})$ and $70 \% \mathrm{HClO}_{4}(1.43 \mathrm{~g}$, $10 \mathrm{mmol}$ ) were added, and the reaction mixture was stirred at room temperature. In all batches, the experimental conditions (e.g., stirring speed, the size of the magnetic bar and reaction flask) were similarly maintained. The effects of various parameters such as the amount of catalyst, oxidant, $\mathrm{NaHCO}_{3}$, and solvent were checked to optimize the conditions for the best performance of the catalyst. After $1 \mathrm{~h}$, the products were extracted in the hexane layer and injected into the GC. The identities of all the products were confirmed by GC-MS.

\section{Results and discussion}

\section{Synthesis}

In the present study, three dioxidovanadium(v) complexes $\left(\mathrm{HNEt}_{3}\right)\left[\mathrm{VO}_{2}(\mathrm{~L})^{1-3}\right]$ (1-3) were synthesized from azohydrazone ligands $\left[\mathbf{H}_{2} \mathbf{L}^{1-3}\right]$. The synthesis of the complexes is summarized in Scheme 1. The reaction of azohydrazone with $\mathrm{VO}(\mathrm{acac})_{2}$ proceeded smoothly at a molar ratio of $1: 1$ in an alcohol medium in the presence of triethylamine as a base. Single crystals of complexes 1-3 were obtained directly from the slow evaporation of the filtrate of the reaction mixture. Furthermore, the purity of these complexes was confirmed by elemental analyses. NMR spectra and ESI-MS results were consistent with the X-ray structures. The complexes were soluble in $\mathrm{CH}_{3} \mathrm{CN}$, ethanol, methanol, DMF, and DMSO and partially soluble in water. Magnetic susceptibility and molar conductivity data revealed that all the complexes (1-3) were diamagnetic and electrically non-conducting in solution. The detailed characterization of all the complexes has been discussed in the corresponding sections (IR, UV-Vis, NMR, ESI-MS and X-ray crystallography).

\section{Spectral characteristics}

The spectral characteristics of all the ligands $\left(\mathbf{H}_{2} \mathbf{L}^{1-3}\right)$ and complexes (1-3) are provided in the Experimental section. The FTIR spectra of the ligands show a broad band in the range of 3202$3412 \mathrm{~cm}^{-1}$ due to the stretching vibration of the $-\mathrm{OH}$ group. Due to the presence of the - $\mathrm{NH}$ group in the ligand, a broad band was observed at 3056-3059 $\mathrm{cm}^{-1}$, while the band for $-\mathrm{C}=\mathrm{O}$ stretching frequency was obtained in the range of $1644-1675 \mathrm{~cm}^{-1}$. The bands for the stretching frequencies of $-\mathrm{C}=\mathrm{N}$ and
$-\mathrm{N}=\mathrm{N}$ were obtained in the ranges of $1612-1625 \mathrm{~cm}^{-1}$ and 1494-1522 $\mathrm{cm}^{-1}$, respectively. The disappearance of the $-\mathrm{NH}$, $-\mathrm{C}=\mathrm{O}$, and $-\mathrm{OH}$ stretching bands in the IR spectra of the complexes (1-3) indicated the formation of metal complexes. However, there was a peak for the pending phenolic $\mathrm{OH}(2)$ and naphthoic $\mathrm{OH}$ (3) groups present in the ligand backbone in the range of $3442-3550 \mathrm{~cm}^{-1}$. The sharp peak at $1609-1614 \mathrm{~cm}^{-1}$ was probably due to the $-\mathrm{C}=\mathrm{N}-$ moiety in the formed complex. $^{32}$ The presence of two strong peaks in the range of 942-960 $\mathrm{cm}^{-1}$ was due to $\mathrm{V}=\mathrm{O}$ stretching, which indicated the presence of the dioxido group in the complexes. ${ }^{10 a, c, 33}$

The electronic spectra of all the complexes were recorded in DMSO and showed a similar pattern. They exhibited medium intensity bands in the range of 396-390 nm, which could be assigned to ligand-to-metal charge transfer (LMCT); they also displayed strong intensity bands within the 261-342 nm range due to ligand-centered transitions. ${ }^{32 a, b}$ A representative absorbance spectrum of $\mathbf{1}$ is given in Fig. 1 .

The ${ }^{1} \mathrm{H}$ and ${ }^{13} \mathrm{C}$ NMR spectra of all ligands and their corresponding compounds were recorded in $\mathrm{DMSO}^{-\mathrm{d}_{6}}$; the data are given in the experimental section. The ${ }^{1} \mathrm{H}$ NMR spectrum of the free ligands exhibits singlet resonance in the range of $\delta=12.23-11.88 \mathrm{ppm}$ due to the $-\mathrm{OH}$ group. However, the ligands $\mathbf{H}_{2} \mathbf{L}^{2}$ and $\mathbf{H}_{2} \mathbf{L}^{3}$ exhibit one extra singlet peak in the $\delta=12.01-11.88$ ppm region for phenolic $\mathrm{OH}\left(\mathbf{H}_{2} \mathbf{L}^{2}\right)$ and

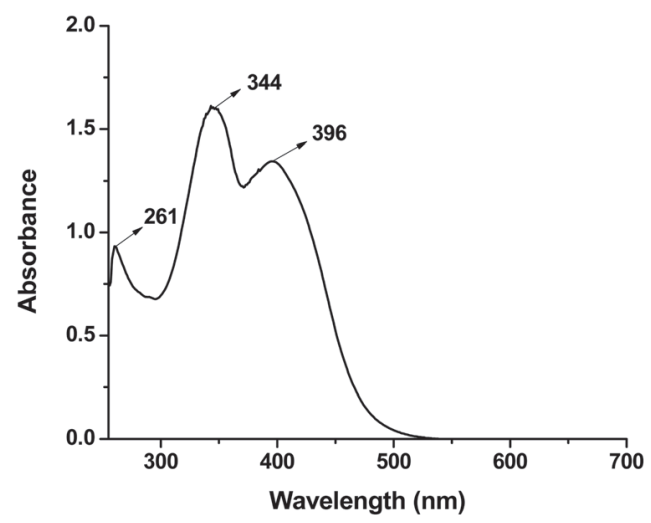

Fig. 1 UV-vis spectra of $1\left(1.5 \times 10^{-4} \mathrm{M}\right)$ in DMSO.

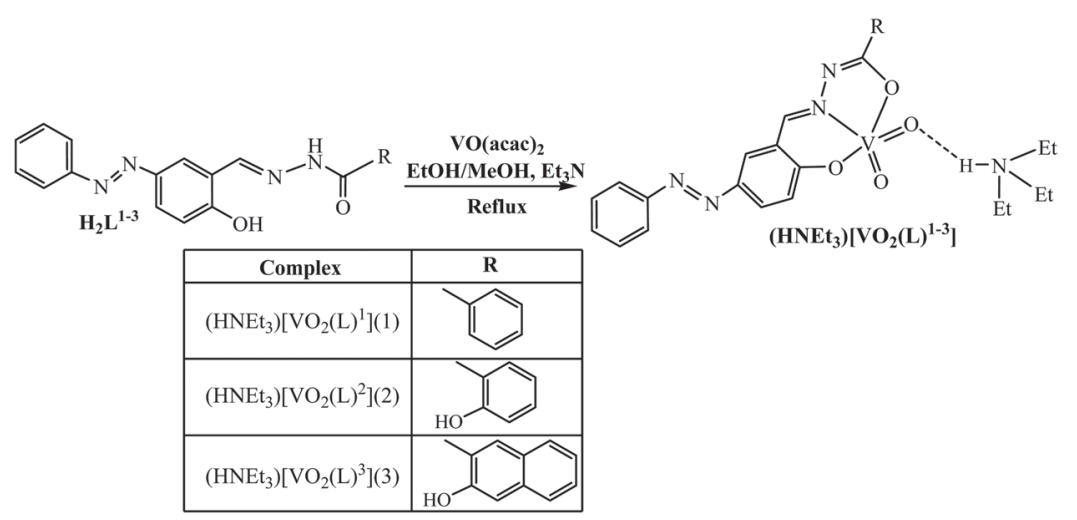

Scheme 1 Schematic representation for the synthesis of $\left(\mathrm{HNEt}_{3}\right)\left[\mathrm{VO}_{2}(\mathrm{~L})^{1-3}\right](\mathbf{1}-\mathbf{3})$. 
naphthoic $\mathrm{OH}\left(\mathbf{H}_{2} \mathbf{L}^{3}\right)$. The singlets in the $\delta=11.83-11.82 \mathrm{ppm}$ and $\delta=8.80-8.78 \mathrm{ppm}$ ranges are due to the $-\mathrm{NH}$ group and the azomethine $-\mathrm{CH}$ proton, respectively. The aromatic protons of the ligands were clearly observed in the expected $\delta=8.48-6.9 \mathrm{ppm}$ region as multiplets. ${ }^{32 a, b}$ In the NMR spectra of complexes 1-3, the peak for the aromatic $-\mathrm{OH}$ and $-\mathrm{NH}$ protons disappeared due to deprotonation at the time of complexation, while the peak in the $\delta=12.15-12.04 \mathrm{ppm}$ region was retained for that of the pending phenolic $\mathrm{OH}(2)$ and naphthoic $\mathrm{OH}(3)$ groups present in the ligand backbone. The signal for the azomethine $-\mathrm{CH}$ proton in the complexes appeared in the range of $\delta=9.37-9.20$. The aromatic signals for the complexes appeared in the range of $\delta=9.0-6.9 \mathrm{ppm}$ as a multiplet. There were two additional peaks observed at the aliphatic region, i.e., at $\delta=3.08$ and at $\delta=1.15 \mathrm{ppm}$, which could be attributed to the presence of a triethylamine moiety. In the ${ }^{13} \mathrm{C}$ NMR spectra of the ligands $\mathbf{H}_{2} \mathbf{L}^{1-3}$, spectral signals for aromatic carbons were found in the downfield region in the range of $\delta=168.49-111.03 \mathrm{ppm}$. In contrast, in the ${ }^{13} \mathrm{C}$ NMR spectra of complexes 1-3, signals for aromatic carbons were found in the downfield region in the range of $\delta=170.99-110.75 \mathrm{ppm}$. Also, two additional peaks were found in the upfield region $(\delta=46.27-9.12)$ due to the presence of two aliphatic carbon atoms $\left(-\mathrm{CH}_{2} \mathrm{CH}_{3}\right)$ of the triethylamine group. The ${ }^{51} \mathrm{~V}$ NMR spectra of 1-3 showed a singlet from $\delta-537$ to $-529 \mathrm{ppm}$. The chemical shifts obtained in this range were typical for the dioxidovanadium(v) species. ${ }^{10 a, c}$

The mass spectra of all the complexes were recorded in methanol in the ESI mode by applying a complex concentration of $100 \mathrm{pmol} \mu \mathrm{L}^{-1}$. The characteristic ion peaks for 1-3 appear at $m / z 425.1\left[\mathrm{M}-\left(\mathrm{Et}_{3} \mathrm{NH}\right)^{+}\right]^{+}, 441.2\left[\mathrm{M}-\left(\mathrm{Et}_{3} \mathrm{NH}\right)^{+}\right]^{+}$and 491.1 $\left[\mathrm{M}-\left(\mathrm{Et}_{3} \mathrm{NH}\right)^{+}\right]^{+}$, respectively, in the negative ion mode. Fig. S1 (ESI $\dagger$ ) depicts the representative ESI-MS spectrum of $\mathbf{1}$.

\section{Electrochemical properties}

The redox properties of the complexes 1-3 were studied in DMSO solutions in the presence of $0.1 \mathrm{M}$ TBAP as the electrolyte using SCE as the reference electrode, Pt as the working electrode, and a Pt wire as the auxiliary electrode at variable scan rates of 50,100 and $150 \mathrm{mV} \mathrm{s}^{-1}$. The voltammograms of all the complexes show a similar pattern, and the redox potential data of all the complexes are summarized in Table 2. As a representative, the voltammogram of $\mathbf{1}$ has been discussed herein and depicted in Fig. 2; the voltammograms for 2 and 3 are given in Fig. S2 and S3 (ESI $\dagger$ ). There were irreversible singleelectron cathodic responses of 1 at $-0.33,-0.66$ and $-1.25 \mathrm{~V}$ and an anodic response at $0.71 \mathrm{~V}$, which may be assigned to

Table 2 Cyclic voltammetric results ${ }^{a}$ of $1-3$ at $298 \mathrm{~K}$ in DMSO

\begin{tabular}{lll}
\hline Complex & $E_{1 / 2}^{\mathrm{c}}(\mathrm{V})$ & $\Delta E_{\mathrm{P}}^{\mathrm{c}}(\mathrm{mV})$ \\
\hline $\mathbf{1}$ & -1.61 & 249 \\
$\mathbf{2}$ & -1.58 & 248 \\
$\mathbf{3}$ & -1.55 & 240
\end{tabular}

${ }^{a}$ In DMSO at variable scan rates of 50,100 and $150 \mathrm{mV} \mathrm{s}^{-1} \cdot E_{1 / 2}^{\mathrm{c}}=\left(E_{\mathrm{P}}^{\mathrm{a}}+E_{\mathrm{P}}^{\mathrm{c}}\right) / 2$, where $E_{\mathrm{P}}^{\mathrm{a}}$ and $E_{\mathrm{P}}^{\mathrm{c}}$ are the anodic and cathodic peak potentials $v s$. SCE, respectively. $\Delta E_{\mathrm{P}}^{\mathrm{c}}=E_{\mathrm{P}}^{\mathrm{a}}-E_{\mathrm{P}}^{\mathrm{c}}$.

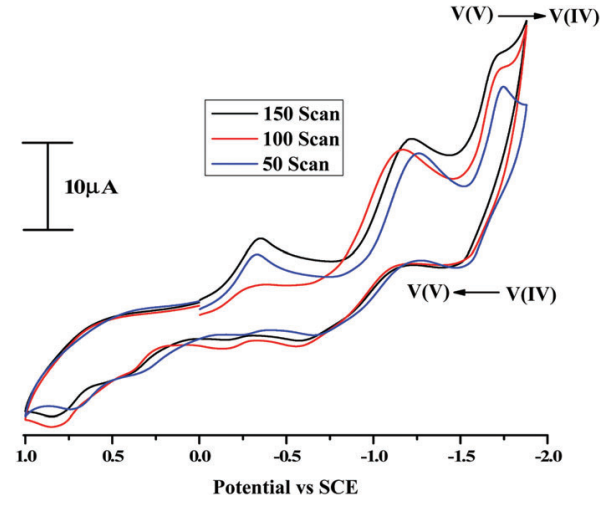

Fig. 2 Cyclic voltammogram of $1\left(10^{-3} \mathrm{M}\right)$ in DMSO.

ligand-centred reduction and oxidation, respectively. Conversely, the complex displayed a quasi-reversible single-electron transfer redox process at the $E_{1 / 2}$ value of $-1.61 \mathrm{~V}$, which was ascribed to the $\mathrm{V}(\mathrm{v}) / \mathrm{V}(\mathrm{Iv})$ reduction couple of $\mathbf{1}$ containing the reduced ligand. ${ }^{34}$

As a representative, the voltammogram of the ligand $\mathbf{H}_{2} \mathbf{L}^{\mathbf{1}}$ is shown in Fig. S4 (ESI $\dagger$ ). The voltammograms at different scan rates were compared to confirm the quasi-reversible nature of the redox processes. Also, identical experimental conditions were maintained to verify the single-electron processes, and its current height was compared with that of the standard ferrocene-ferrocenium couple.

\section{X-ray structure description}

Even though the preliminary characterization data (elemental analysis, ${ }^{1} \mathrm{H}$ and ${ }^{13} \mathrm{C}$ NMR and IR) suggested the presence of a ligand, two oxido groups and a counter ion in complexes 1-3, they could neither manifest any definite stereochemistry for the complexes nor predict the coordination mode of $\mathbf{H}_{2} \mathbf{L}^{\mathbf{1 - 3}}$. In order to validate the coordination mode of the ligands and the supramolecular geometries possible in these complexes, the structures of 1-3 were determined via X-ray crystallography. The X-ray structures of the complexes revealed that all the evidence provided by the ${ }^{1} \mathrm{H}$ NMR spectra was correct. The relevant bond parameters are mentioned in Table 3, while the molecular structure along with the atom numbering scheme for $1-3$ is depicted in Fig. 3. The structure revealed that the vanadium atom, which is present in a penta-coordinated fashion, was bound by a tridentate binegative anion coordinating via phenolate oxygen - $\mathrm{O}(2)$, imine nitrogen - $\mathrm{N}(2)$ and enolic oxygen - $\mathrm{O}(1)$ and two oxido - $\mathrm{O}(3), \mathrm{O}(4)$ atoms; the charge of this moiety was balanced by a triethylamine cation. The resulting $\mathrm{O}_{4} \mathrm{~N}$ donor set in complexes 1-3 was distorted toward square pyramidal geometry based on a $\tau$ value in the range of $0.08-0.24,{ }^{29}$ which is evident from the ideal values of 0.0 and 1.0 for square pyramidal and trigonal bipyramidal geometries, respectively. ${ }^{35}$

The azohydrazone ligands form six-membered and fivemembered chelate rings at the $\mathrm{V}(\mathrm{v})$ metal center with $\mathrm{O}(2)-$ $\mathrm{V}(1)-\mathrm{N}(2)$ and $\mathrm{O}(1)-\mathrm{V}(1)-\mathrm{N}(2)$ bite angles of $82.1(2)^{\circ}-81.79(6)^{\circ}$ and $73.9(2)^{\circ}-73.2(2)^{\circ}$, respectively. One of the two oxido groups, 
Table 3 Selected geometric parameters for 1 -3

\begin{tabular}{lrrr}
\hline & 1 & 2 & 3 \\
\hline Bond distances (̊) & & & \\
$\mathrm{V}(1)-\mathrm{O}(1)$ & $1.956(5)$ & $1.970(5)$ & $1.982(1)$ \\
$\mathrm{V}(1)-\mathrm{O}(2)$ & $1.903(5)$ & $1.910(5)$ & $1.902(1)$ \\
$\mathrm{V}(1)-\mathrm{O}(3)$ & $1.610(5)$ & $1.603(5)$ & $1.611(1)$ \\
$\mathrm{V}(1)-\mathrm{O}(4)$ & $1.636(5)$ & $1.639(5)$ & $1.636(2)$ \\
$\mathrm{V}(1)-\mathrm{N}(2)$ & $2.146(6)$ & $2.124(6)$ & $2.150(1)$ \\
$\mathrm{N}(1)-\mathrm{N}(2)$ & $1.398(8)$ & $1.416(8)$ & $1.392(2)$ \\
$\mathrm{N}(3)-\mathrm{N}(4)$ & $1.226(8)$ & $1.233(10)$ & $1.258(2)$ \\
& & & \\
$\mathrm{Bond}$ angles $\left({ }^{\circ}\right)$ & & & $73.53(5)$ \\
$\mathrm{O}(1)-\mathrm{V}(1)-\mathrm{N}(2)$ & $73.2(2)$ & $73.9(2)$ & $81.79(6)$ \\
$\mathrm{O}(2)-\mathrm{V}(1)-\mathrm{N}(2)$ & $82.1(2)$ & $81.2(2)$ & $151.65(6)$ \\
$\mathrm{O}(2)-\mathrm{V}(1)-\mathrm{O}(1)$ & $148.0(2)$ & $149.1(2)$ & $112.22(7)$ \\
$\mathrm{O}(3)-\mathrm{V}(1)-\mathrm{N}(2)$ & $106.8(2)$ & $109.0(3)$ & $101.14(7)$ \\
$\mathrm{O}(3)-\mathrm{V}(1)-\mathrm{O}(1)$ & $102.0(3)$ & $101.4(3)$ & $100.96(7)$ \\
$\mathrm{O}(3)-\mathrm{V}(1)-\mathrm{O}(2)$ & $104.4(3)$ & $103.8(3)$ & $136.99(7)$ \\
$\mathrm{O}(3)-\mathrm{V}(1)-\mathrm{O}(4)$ & $109.7(3)$ & $109.1(3)$ & $92.44(7)$ \\
$\mathrm{O}(4)-\mathrm{V}(1)-\mathrm{N}(2)$ & $143.1(3)$ & $141.5(3)$ & $96.31(7)$ \\
$\mathrm{O}(4)-\mathrm{V}(1)-\mathrm{O}(1)$ & $93.7(2)$ & $93.3(2)$ & \\
$\mathrm{O}(4)-\mathrm{V}(1)-\mathrm{O}(2)$ & $94.0(3)$ & $95.1(3)$ & \\
& & &
\end{tabular}

i.e., $\mathrm{O}(4)$ is located terminally at the apical position of the square pyramid and trans to the imine nitrogen $\mathrm{N}(2)$, while the other oxido group $\mathrm{O}(3)$ is located in the axial plane. The $\mathrm{V}-\mathrm{O}(4)$ bond distances are slightly longer than those of $\mathrm{V}-\mathrm{O}(3)$ due to the trans effect; however, such bond lengths are longer than those of the monoalkoxido vanadium(v) complexes containing only one terminal oxygen atom. ${ }^{32 b}$ The angle between the two oxido atoms $\mathrm{O}(3)$ and $\mathrm{O}(4)$, i.e., $\mathrm{O}(3)-\mathrm{V}(1)-\mathrm{O}(4)$ is in the range of $110.31(8)^{\circ}-109.1(3)^{\circ}$. Both $\mathrm{V}=\mathrm{O}$ bonds are shorter than their corresponding $\mathrm{V}-\mathrm{O}$ (phenolate) and $\mathrm{V}-\mathrm{O}$ (enolate) bonds, suggesting the stronger binding of the oxido group compared to those of the phenolate and enolate oxygen atoms. ${ }^{36}$

The supramolecular architectures showed that the complexes were bound to the triethylamine cation moiety by $\mathrm{V}=\mathrm{O}(4) \cdots \mathrm{H}-\mathrm{N}(5)$ hydrogen bonding (red dotted lines, Fig. 4), whereas there was additional intramolecular hydrogen bonding $\mathrm{O}(5)-\mathrm{H} \cdots \mathrm{N}(1)$ present for complexes 2 and 3 (blue dotted lines, Fig. 4(b) and (c)), involving the hydrogen of naphthoic $\mathrm{OH}$ and the imine nitrogen $\mathrm{N}(1)$ atom. The detailed parameters of the classical hydrogen bonding of the complexes (1-3) are listed in Table 4.

\section{Cytotoxic study}

MTT assay. Following successful synthesis and characterization, the in vitro cytotoxicity of the complexes 1-3 was evaluated by determining the viability of cervical cancer (HeLa) and human colon cancer (HT-29) cell lines through MTT assays. These studies were performed in order to probe and observe the influence of the vanadium metal centre in the aroylhydrazone ligand environment appended with an azobenzene moiety on the antiproliferative efficacy of the reported complexes. The analysis revealed that all the complexes were quite effective in killing the cancer cells and were highly cytotoxic even at a low concentration of $3 \mu \mathrm{g} \mathrm{mL} \mathrm{mL}^{-1}$. It was also observed that upon increasing the time of exposure of the complexes $\left(3 \mu \mathrm{g} \mathrm{mL}^{-1}\right)$ from 12 to $24 \mathrm{~h}$, there was gradual decrease in HeLa and HT-29 cell viabilities (Fig. 5A and B). Following that, after $48 \mathrm{~h}$ of exposure, there were almost 60 and $70 \%$ cell deaths with respect to the control for HeLa and HT-29 cell lines, respectively, at the highest concentration of the complexes $\left(100 \mu \mathrm{g} \mathrm{mL}{ }^{-1}\right)$ tested
1

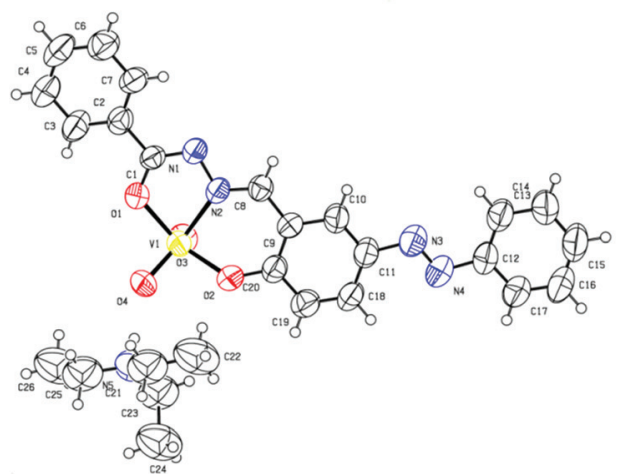

2

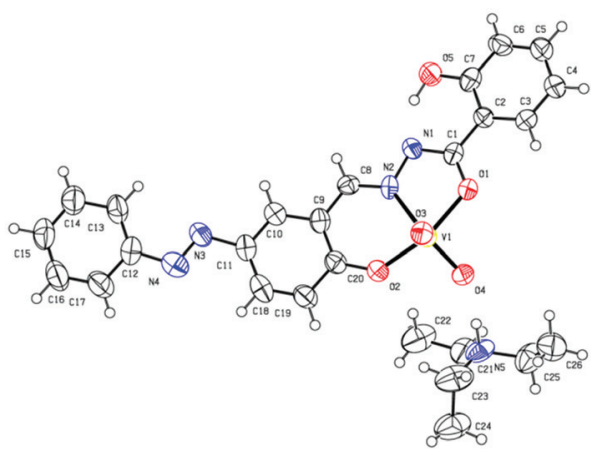

3

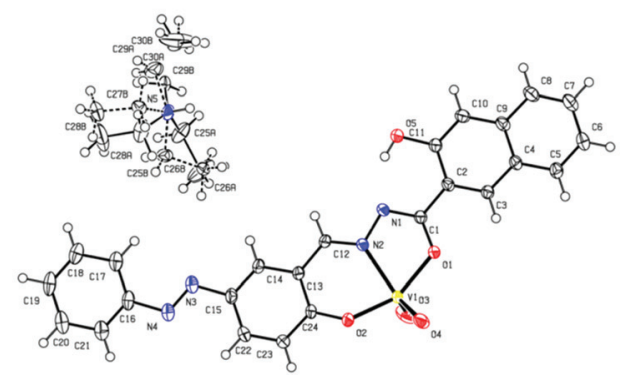

Fig. 3 The molecular structures of 1-3 with the atomic numbering scheme used. 
(a)

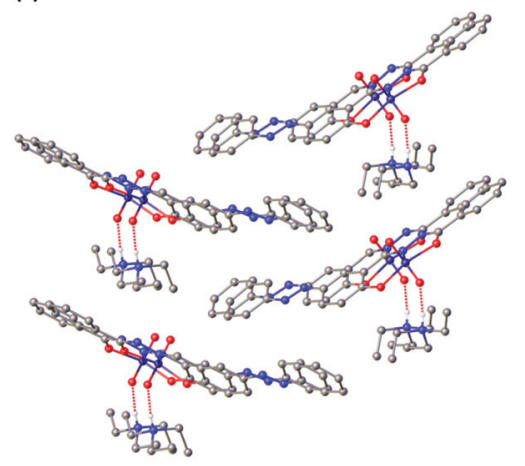

(b)

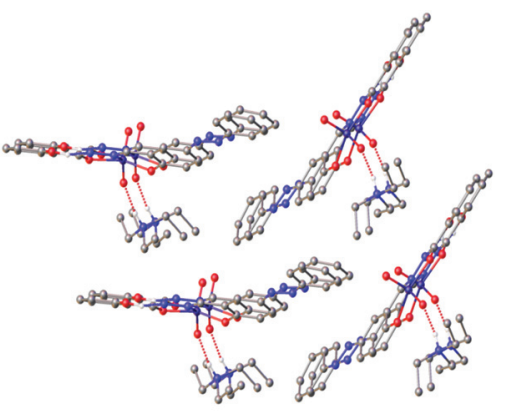

(c)

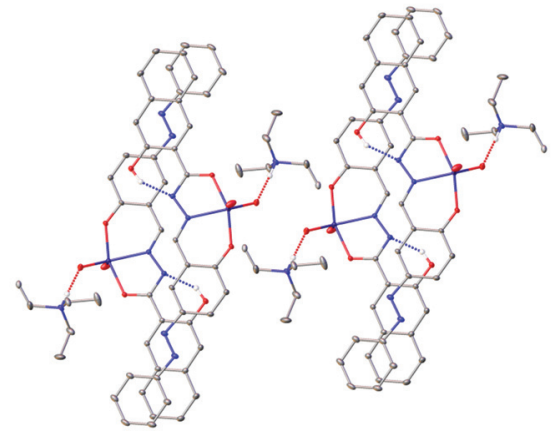

Fig. 4 Supramolecular architectures of (a) 1, (b) 2 and (c) 3. Dashed lines represent intramolecular (blue) and intermolecular (red) hydrogen bonds; for clarity, only hydrogen atoms involved in these interactions are shown. For (c), only the more populated location of the disordered protonated amine is shown.

Table 4 Hydrogen bond geometry for 1-3

\begin{tabular}{|c|c|c|c|c|c|}
\hline Complex & $\mathrm{D}-\mathrm{H} \cdots \mathrm{A}$ & $\mathrm{D}-\mathrm{H}[\AA]$ & $\mathrm{H} \cdots \mathrm{A}[\AA]$ & $\mathrm{D} \cdots \mathrm{A}[\AA]$ & $\mathrm{D}-\mathrm{H} \cdots \mathrm{A}\left[{ }^{\circ}\right]$ \\
\hline 1 & N5-H5N-O4 & $0.86(3)$ & $1.81(3)$ & $2.668(9)$ & $176(1)$ \\
\hline \multirow[t]{2}{*}{2} & N5-H5N-O4 & $0.90(3)$ & $1.79(3)$ & $2.681(9)$ & $169(1)$ \\
\hline & O5-H5O-N1 & $0.95(8)$ & $1.77(5)$ & $2.589(9)$ & $142(4)$ \\
\hline \multirow[t]{2}{*}{3} & 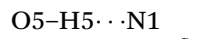 & $0.83(3)$ & $1.84(3)$ & $2.605(2)$ & $151(2)$ \\
\hline & N5-H5B $\cdots 4^{a}$ & $0.86(2)$ & $1.86(2)$ & $2.711(2)$ & $172(2)$ \\
\hline
\end{tabular}

(Fig. 5C and D). These sets of complexes showed similar cytotoxicities towards both cancer cells.

The complexes exhibited $\mathrm{IC}_{50}$ values in the ranges of 4.7-5.5 $\mu \mathrm{M}$ and 5.29-7.48 $\mu \mathrm{M}$ against HeLa and HT-29 cells (Table 5), respectively. Out of the three complexes, the maximum cytotoxicity against HeLa cells was shown by 3 , while the other two complexes provided nearly the same $\mathrm{IC}_{50}$ values. A similar trend was also seen for HT-29 cells, where 3 showed maximum cytotoxicity, followed by 2 and $\mathbf{1}$. Also, it seems that there was a tendency for higher toxicity of the compounds tested for HeLa cells than that of the compounds tested for HT-29 cells. The complexes showed higher antiproliferative activity as compared to their corresponding ligands and metal precursors towards both cancer cells $\left(\mathrm{IC}_{50}\right.$ values $\left.>100 \mu \mathrm{M}\right)$. In order to determine the cytotoxic effect of the present complexes on the viability of physiological cells, we performed a similar study on human skin keratinocyte cells (НaCaT). It was noticed that there was subtle decrease in the HaCaT cell viability upon increasing the time of exposure of the complexes ( $5 \mu \mathrm{g} \mathrm{mL} \mathrm{m}^{-1}$ ) from 12 to $24 \mathrm{~h}$ (Fig. 5E).
The results (Fig. 5F and Table 5) signify that unlike the observations for the cancers cells, the complexes were less toxic towards HaCaT at lower concentrations and were cytotoxic only at concentrations of $50 \mu \mathrm{g} \mathrm{mL} \mathrm{m}^{-1}$ and higher after $48 \mathrm{~h}$ of exposure. This can be an indication that the complexes may be selective in nature towards cancer cells. A feasible rationalization would be the decrease in the polarity of the ligand and the central metal ion after charge equilibration, which aids in the permeation of the complexes through the lipid layer and the possible higher uptake by the cell membrane. ${ }^{37}$ This consequently led to synergistic effects and improved the cytotoxicity of the overall complex. Furthermore, the presence of a naphthyl substituent ${ }^{13}$ in the ligand backbone could be attributed to the lower $\mathrm{IC}_{50}$ value of 3 in comparison to that of the other complexes.

Under similar experimental conditions, commonly used chemotherapeutic drugs such as cisplatin and cyclophosphamide have shown comparable effectiveness against HeLa cells with IC $_{50}$ values of 12.2 and $1689 \mu \mathrm{M}$ as well as against HT-29 cells with $\mathrm{IC}_{50}$ values of 70 and $21.5 \mu \mathrm{M}$, respectively. ${ }^{38}$ The present series of vanadium complexes in the azohydrazone ligand environment showed improved in vitro cytotoxicity results against HT-29 cell lines in comparison to our previously reported arylazovanadium(Iv) complexes $^{10 e}$ and other vanadium complexes $(>47 \mu \mathrm{M}$ against HT-29 for [VO(sal-L-tryp)(acetylethTSC)] $\mathrm{C}_{2} \mathrm{H}_{5} \mathrm{OH} \quad\left[\mathrm{VO}(\right.$ sal-L-tryp)(Me-ATSC) $]$ and $\left[\mathrm{VO}\left(\right.\right.$ sal- $\mathrm{L}^{-}$ tryp) $\left(\mathrm{N}\right.$-ethhymethohcarbthio)] $\left.\mathrm{H}_{2} \mathrm{O}\right),{ }^{39}$ whereas the antiproliferative potential of 1-3 was also better than or comparable to our previously reported results for vanadium ${ }^{10}$ and molybdenum hydrazone ${ }^{40}$ complexes against HeLa cells. 

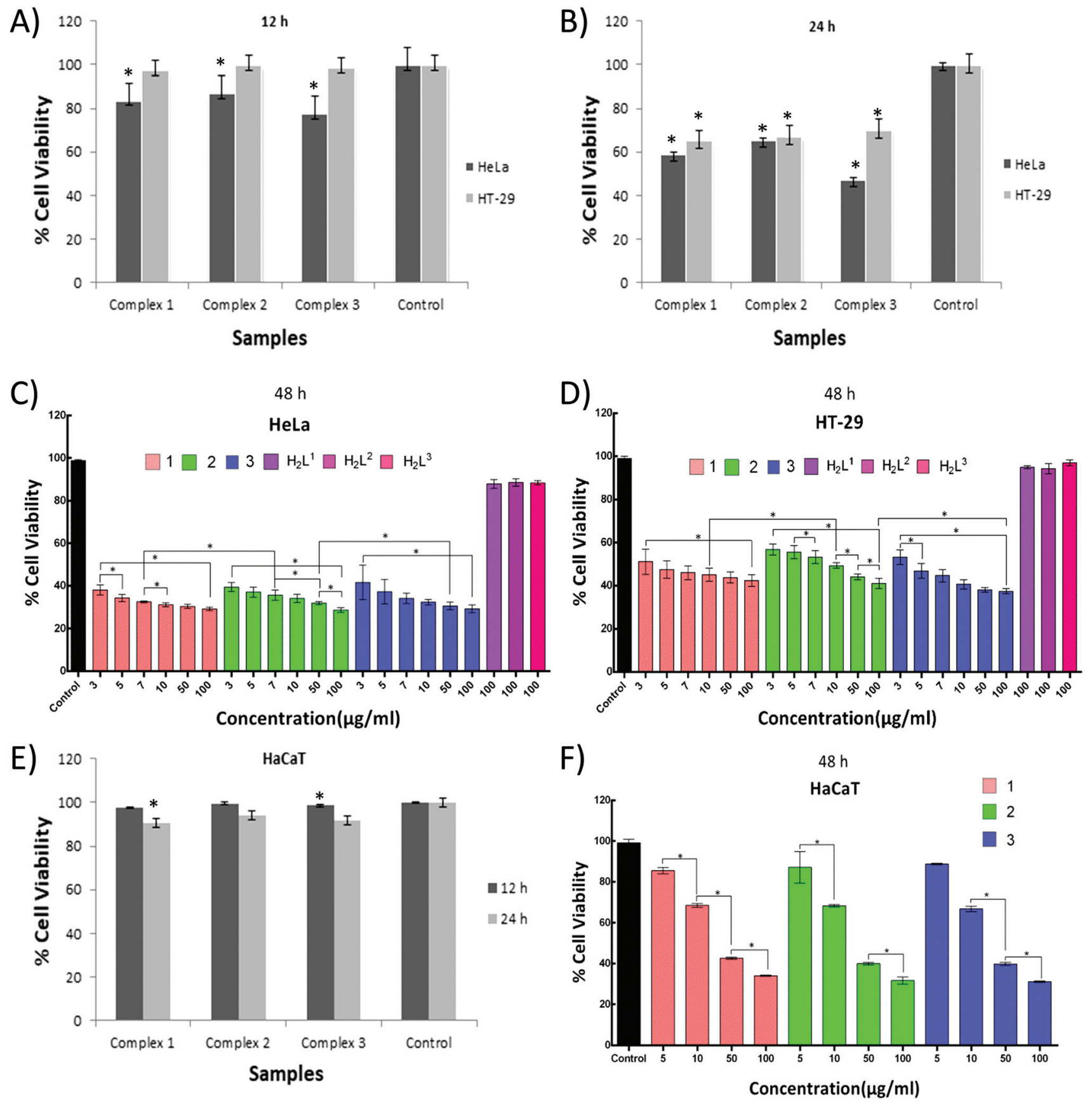

Fig. 5 The effect of 1-3 (3 $\left.\mu \mathrm{g} \mathrm{mL}^{-1}\right)$ on the cell viability of HeLa and HT-29 cells after $12 \mathrm{~h}(\mathrm{~A})$ and $24 \mathrm{~h}(\mathrm{~B})$ of exposure and after $48 \mathrm{~h}(\mathrm{C}$ and $\mathrm{D})$ of exposure, taking $3,5,7,10,50,100 \mu \mathrm{g} \mathrm{mL}^{-1}$ concentrations of the complexes. The effect of $1-3\left(5 \mu \mathrm{g} \mathrm{mL} \mathrm{m}^{-1}\right)$ on the cell viability of HaCaT after $12 \mathrm{~h}$ and $24 \mathrm{~h}(\mathrm{E})$ of exposure and after $48 \mathrm{~h}$ (F) of exposure, taking 5, 10,50,100 $\mu \mathrm{g} \mathrm{mL}^{-1}$ concentrations of the complexes. The cell viability was calculated by MTT assay. Data were reported as the mean \pm SD for $n=4$. ${ }^{\star} P<0.05$ was considered statistically significant.

Nuclear staining assay. The mechanism of cell death in response to the treatment with the complexes was studied through the staining of dying cells with DAPI, which is a fluorescence dye specific for nuclei. ${ }^{10 e}$ These DAPI-stained nuclei were used to check the chromatin condensation or fragmentation during apoptosis (type I programmed cell death), which is a hallmark feature of nuclear alteration. ${ }^{10}$ Many cytotoxic agents and clinically active compounds are known to disrupt the nuclear integrity and cytoskeletal structure of the cells during their course of action, ${ }^{41}$ and these include cisplatin (complexation of nucleic acids) ${ }^{42}$ doxorubicin (intercalation of nucleic acids) ${ }^{43}$ and taxol (stabilization of microtubules). ${ }^{44}$ Fig. 6 depicts the DAPI staining images of the complexes against HeLa and HT-29 cell lines. It can be seen from the images that the number of DAPI-stained nuclei decreased in comparison to the control for both cell lines. Along with this, the treated HT-29 cells exhibited shrinking morphology and condensed chromatin bodies for all the complexes. In addition, the treated HeLa cells also revealed nuclear blebbing and fragmentation. 
Table $5 \quad I C_{50}$ values of 1-3 against HeLa, HT-29 and HaCaT cells after $48 \mathrm{~h}$ of exposure

\begin{tabular}{|c|c|c|c|}
\hline \multirow[b]{2}{*}{ Complex } & \multicolumn{2}{|l|}{$\mathrm{IC}_{50}(\mu \mathrm{M})$} & \multirow[b]{2}{*}{ HaCaT cells } \\
\hline & HeLa cells & HT-29 cells & \\
\hline 1 & $5.5 \pm 0.75$ & $7.48 \pm 1.04$ & $84.68 \pm 0.6$ \\
\hline 2 & $5.46 \pm 1.59$ & $6.73 \pm 0.91$ & $75.15 \pm 3.3$ \\
\hline 3 & $4.7 \pm 0.55$ & $5.29 \pm 1.1$ & $68.71 \pm 0.29$ \\
\hline
\end{tabular}

This phenomenon is a clear indication of apoptosis taking place in the cells. Till date, there are a number of cytotoxic complexes that have reported such a phenomenon and on this basis, we hypothesize that this set of compounds may possess comparable properties. $^{10}$

\section{Catalytic activity studies of 1-3}

Oxidative bromination of thymol. There are various reports in the literature on vanadium complexes behaving as structural and/or functional mimics of vanadium haloperoxidases (VHPOs). ${ }^{45}$ These complexes can catalyze various oxidation reactions in the presence of peroxides ${ }^{46}$ and organic substrates. ${ }^{47}$ Thus, in the first case, the studied complexes (1-3) were used to evaluate their efficiency towards the catalytic oxidative bromination of thymol (a monoterpene) in the presence of $\mathrm{KBr}, 70 \%$ aqueous $\mathrm{HClO}_{4}$ and $30 \% \mathrm{H}_{2} \mathrm{O}_{2}$ in an aqueous solution under appropriate reaction conditions. All reactions were carried out in a $50 \mathrm{~mL}$ reaction flask at room temperature. The bromination reaction occurred on the

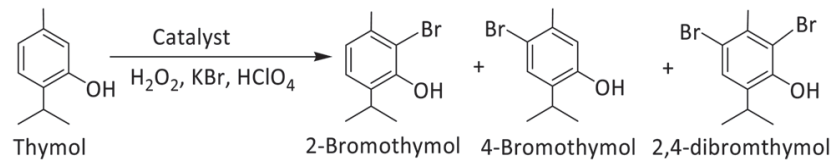

Scheme 2 Products of the oxidative bromination of thymol.

most activated site as a result of electrophilic aromatic substitution in the phenolic ring. Thus, the oxidative bromination of thymol led to the formation of 2-bromothymol and 4-bromothymol, while further bromination of these compounds also provided some 2,4-dibromothymol species (Scheme 2).

In order to obtain the best-suited reaction conditions for maximum oxidative bromination products, the reaction conditions were optimized considering 2 as a representative catalyst. Thus, for $10 \mathrm{mmol}$ of thymol $(1.50 \mathrm{~g})$, three different amounts of the catalyst $(0.0005,0.001,0.002 \mathrm{~g})$, three different amounts of $30 \%$ aqueous $\mathrm{H}_{2} \mathrm{O}_{2}(10,20$ and $30 \mathrm{mmol})$, three different amounts of $\mathrm{KBr}(10,20$ and $30 \mathrm{mmol})$ and three different amounts of $70 \%$ aqueous $\mathrm{HClO}_{4}(10,20$ and $30 \mathrm{mmol}$ ) were added in three equal portions to the reaction mixture. The first portion was added at $t=0$ and the other two portions were added at $30 \mathrm{~min}$ intervals to $20 \mathrm{~mL}$ of water; the reaction was carried out at room temperature for $2 \mathrm{~h}$. The amount of $\mathrm{HClO}_{4}$ added to the reaction mixture was found to be crucial to obtain effective catalytic bromination and selectivity of products.

(1)
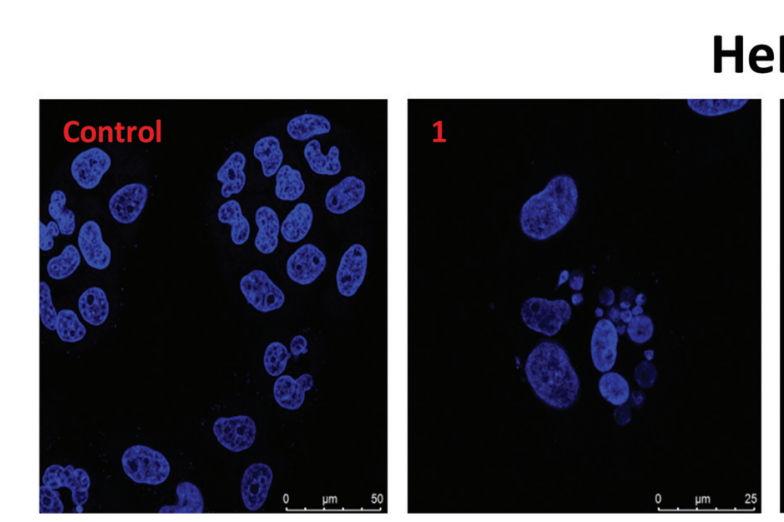

\section{HeLa}
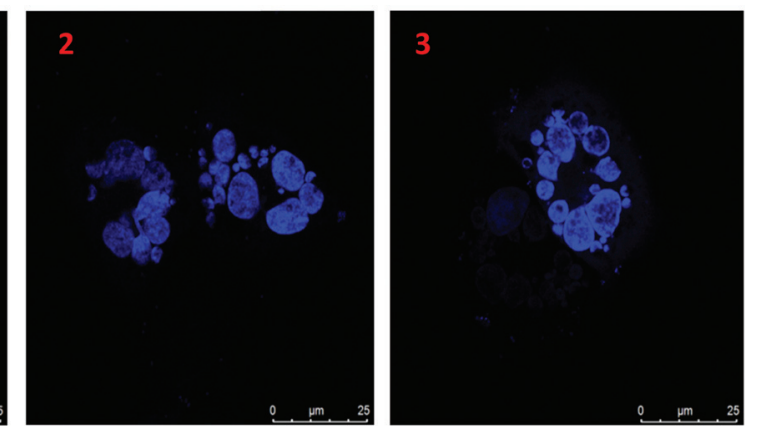

HT-29
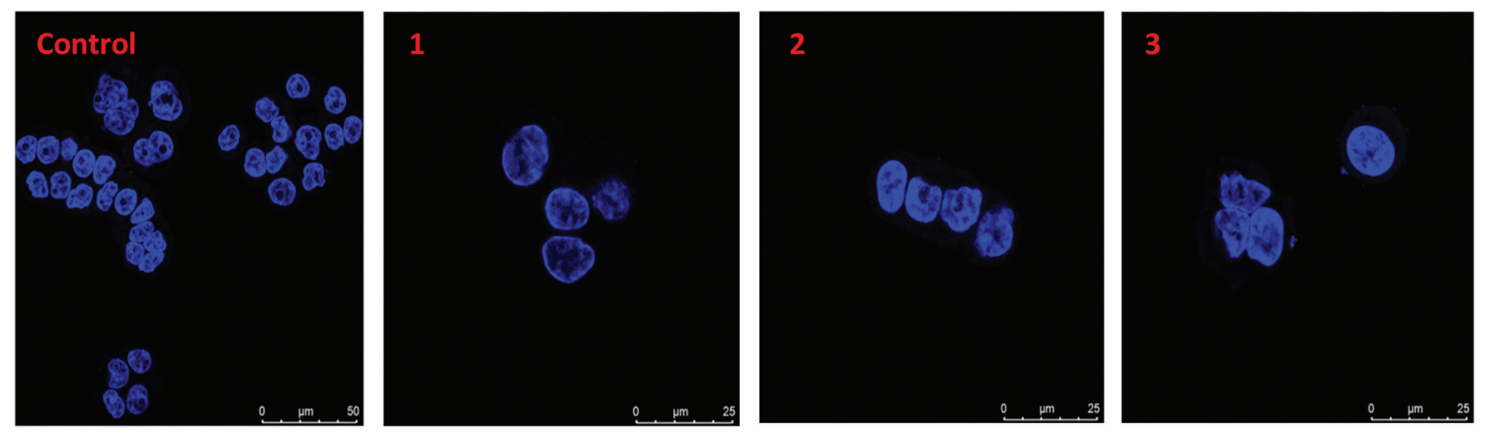

Fig. 6 Morphologies of HeLa (upper panel) and HT-29 (lower panel) cells treated with complexes 1-3 at a concentration of $10 \mu \mathrm{g} \mathrm{mL}^{-1}$ for $24 \mathrm{~h}$. The cells were visualized under a confocal microscope after staining with DAPI (blue color, nucleus). The scale bar corresponds to $50 \mu \mathrm{m}$ for the control, while for the complexes, the scale bar corresponds to $25 \mu \mathrm{m}$. 
(a)
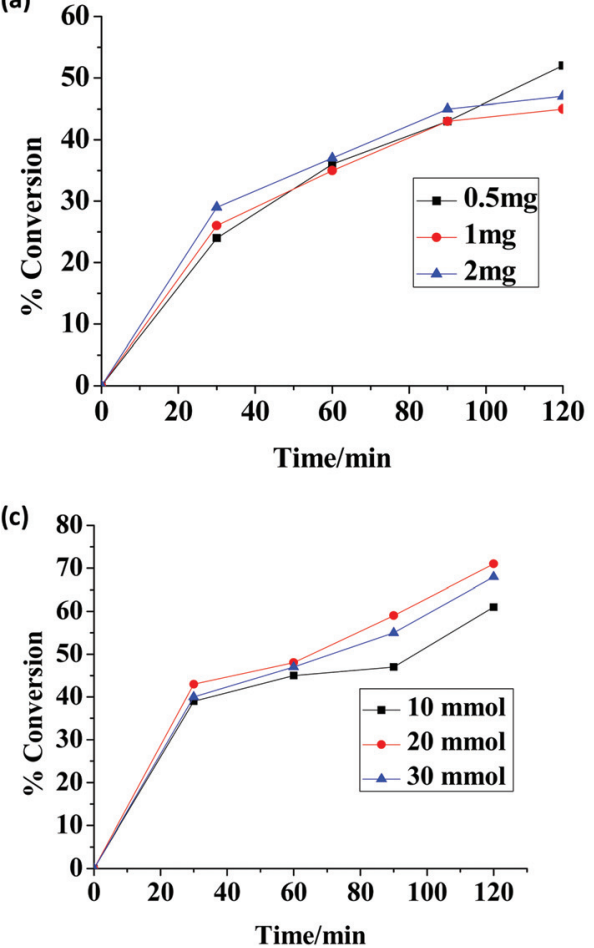

(b)

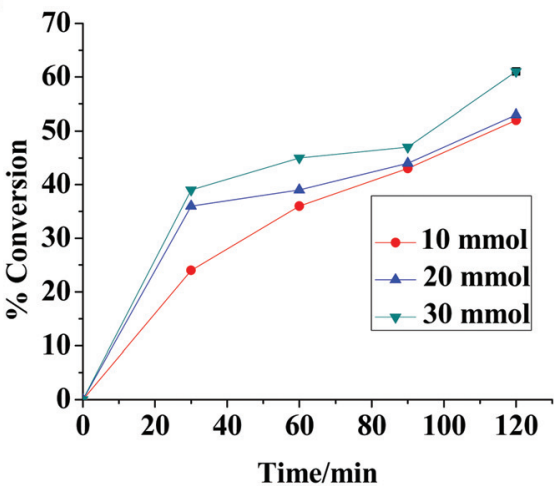

(d)

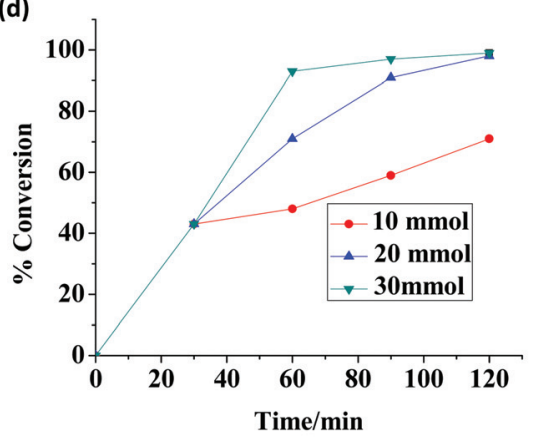

Fig. 7 (a) The effect of variation of the amount of catalyst 2 on the oxidative bromination of thymol. Reaction conditions: thymol (1.5 g, 10 mmol), $30 \%$ aqueous $\mathrm{H}_{2} \mathrm{O}_{2}(1.13 \mathrm{~g}, 10 \mathrm{mmol}), \mathrm{KBr}\left(1.19 \mathrm{~g}, 10 \mathrm{mmol}\right.$ ), and $\mathrm{HClO}_{4}(1.43 \mathrm{~g}, 10 \mathrm{mmol})$ at room temperature. (b) The effect of variation of the amount of oxidant on the oxidative bromination of thymol. Reaction conditions: thymol (1.5 g, $10 \mathrm{mmol})$, catalyst 2 (0.5 mg, $\left.7.5 \times 10^{-4} \mathrm{mmol}\right), \mathrm{KBr}(1.19 \mathrm{~g}, 10 \mathrm{mmol})$ and $\mathrm{HClO}_{4}(1.43 \mathrm{~g}, 10 \mathrm{mmol})$ at room temperature. (c) The effect of varying amounts of additive (KBr) on the oxidative bromination of thymol. Reaction conditions: thymol $(1.5 \mathrm{~g}, 10 \mathrm{mmol})$, catalyst $2\left(0.5 \mathrm{mg}, 7.5 \times 10^{-4} \mathrm{mmol}\right), 30 \%$ aqueous $\mathrm{H}_{2} \mathrm{O}_{2}(3.39 \mathrm{~g}, 30 \mathrm{mmol})$ and $\mathrm{HClO} 4(1.43 \mathrm{~g}, 10 \mathrm{mmol})$ at room temperature. (d) The effect of varying amounts of $\mathrm{HClO}_{4}$ on the oxidative bromination of thymol. Reaction conditions: thymol (1.5 g, 10 mmol), catalyst 2 $\left(0.5 \mathrm{mg}, 7.5 \times 10^{-4} \mathrm{mmol}\right), 30 \%$ aqueous $\mathrm{H}_{2} \mathrm{O}_{2}(3.39 \mathrm{~g}, 30 \mathrm{mmol})$ and $\mathrm{KBr}(2.38 \mathrm{~g}, 20 \mathrm{mmol})$ at room temperature.

The details of all reaction conditions and the corresponding conversions of thymol are summarized in Fig. 7 and Table 6. The data presented in Table 6 are based on two sets of reactions for each experiment, and the obtained conversions are within $\pm 1 \%$. It may be concluded from the data presented in Table 6 that the optimized reaction conditions (entry no. 8) for the best conversion of $10 \mathrm{mmol}(1.50 \mathrm{~g})$ thymol with catalyst 2 include the use of $0.0005 \mathrm{~g}$ catalyst, $30 \mathrm{mmol} 30 \% \mathrm{H}_{2} \mathrm{O}_{2}, 20 \mathrm{mmol} \mathrm{KBr}$, and $20 \mathrm{mmol} 70 \% \mathrm{HClO}_{4}$. Under these conditions, the obtained conversion was $98 \%$, where the selectivity of different major products followed the order 4-bromothymol $(70 \%)>2,4$ dibromothymol $(19 \%)>2$-bromothymol $(11 \%)$.

The other two catalysts, i.e., 1 and 3 were also tested under the above-optimized reaction conditions, and the results are presented in Table 7. It is clear from the data that both complexes show similar catalytic activities (ca. 99\%) (please see Fig. 8 also) along with high turnover frequencies. Again, 4-bromothymol demonstrated the highest selectivity. A blank

Table 6 Conversion of thymol (1.5 g, $0.010 \mathrm{~mol})$ using 2 as a catalyst, turnover frequency, and selectivity of different products after $2 \mathrm{~h}$ of reaction under different reaction conditions

\begin{tabular}{|c|c|c|c|c|c|c|c|c|c|}
\hline \multirow[b]{2}{*}{ Entry } & \multirow[b]{2}{*}{$\mathrm{KBr}[\mathrm{g}(\mathrm{mmol})]$} & \multirow[b]{2}{*}{$\mathrm{H}_{2} \mathrm{O}_{2}[\mathrm{~g}(\mathrm{mmol})]$} & \multirow[b]{2}{*}{$\mathrm{HClO}_{4}[\mathrm{~g}(\mathrm{mmol})]$} & \multirow[b]{2}{*}{ Catalyst [mg (mmol)] } & \multirow[b]{2}{*}{ Conv. $[\%]$} & \multirow[b]{2}{*}{$\mathrm{TOF}\left[\mathrm{h}^{-1}\right]$} & \multicolumn{3}{|c|}{ Selectivity $[\%]^{b}$} \\
\hline & & & & & & & 2-Brth & 4-Brth & 2,4-DiBrth \\
\hline 1 & $1.19(10)$ & $1.13(10)$ & $1.43(10)$ & $0.5\left(7.5 \times 10^{-4}\right)$ & 52 & 3466 & 13 & 82 & 5 \\
\hline 2 & $1.19(10)$ & $1.13(10)$ & $1.43(10)$ & $1\left(1.5 \times 10^{-3}\right)$ & 44 & 1466 & 13 & 84 & 3 \\
\hline 3 & $1.19(10)$ & $1.13(10)$ & $1.43(10)$ & $2\left(3.0 \times 10^{-3}\right)$ & 47 & 783 & 9 & 82 & 8 \\
\hline 4 & $1.19(10)$ & $2.26(20)$ & $1.43(10)$ & $0.5\left(7.5 \times 10^{-4}\right)$ & 53 & 3533 & 10 & 67 & 23 \\
\hline 5 & $1.19(10)$ & $3.39(30)$ & $1.43(10)$ & $0.5\left(7.5 \times 10^{-4}\right)$ & 61 & 4066 & 2 & 81 & 7 \\
\hline 6 & $2.38(20)$ & $3.39(30)$ & $1.43(10)$ & $0.5\left(7.5 \times 10^{-4}\right)$ & 71 & 4733 & 11 & 73 & 16 \\
\hline 7 & $3.57(30)$ & $3.39(30)$ & $1.43(10)$ & $0.5\left(7.5 \times 10^{-4}\right)$ & 68 & 4533 & 12 & 77 & 11 \\
\hline $8^{a}$ & $2.38(20)$ & $3.39(30)$ & $2.86(20)$ & $0.5\left(7.5 \times 10^{-4}\right)$ & 98 & 6533 & 11 & 70 & 19 \\
\hline 9 & $3.57(20)$ & $3.39(30)$ & $4.29(30)$ & $0.5\left(7.5 \times 10^{-4}\right)$ & 99 & 6600 & 12 & 46 & 42 \\
\hline
\end{tabular}

${ }^{a}$ The optimized conditions mentioned here are the best among the different sets of reactions carried out. ${ }^{b} 2$-Brth $=2$-bromothymol, 4 -Brth $=4$ bromothymol and 2,4-diBrth = 2,4-dibromothymol. 
Table 7 Conversion, turnover frequency and selectivity parameters for various catalysts for the oxidative bromination of thymol

\begin{tabular}{llllll}
\hline & & \multicolumn{4}{c}{ Selectivity [\%] } \\
\cline { 5 - 6 } Catalyst & TOF $\left[\mathrm{h}^{-1}\right]^{a}$ & Conv. [\%] & 2-Brth & 4-Brth & 2,4-DiBrth \\
\hline $\mathbf{1}$ & 5380 & 99 & 6 & 76 & 18 \\
$\mathbf{2}$ & 6533 & 98 & 11 & 70 & 19 \\
$\mathbf{3}$ & 7173 & 99 & 8 & 77 & 15 \\
Without catalyst & & 38 & 3 & 84 & 13
\end{tabular}

${ }^{a}$ TOF values calculated at $2 \mathrm{~h}$ reaction time.

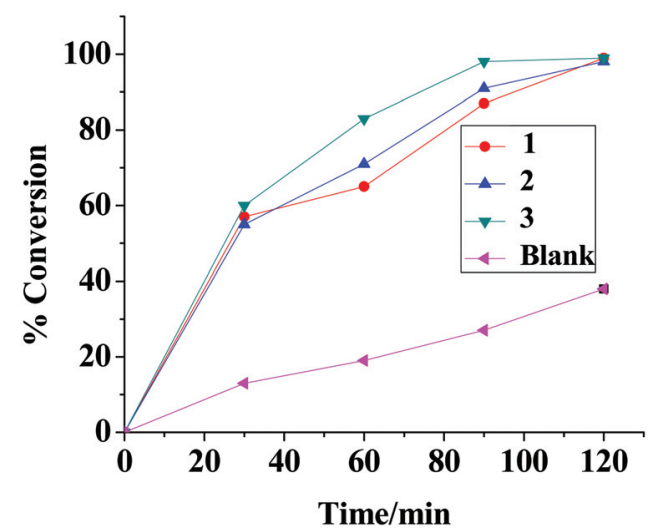

Fig. 8 Plots representing the conversion of thymol in the presence of $\mathbf{1 - 3}$.

reaction under the above reaction conditions led to only $38 \%$ conversion (Table 7).

Comparing the present sets of complexes with those reported in the literature, it was found that they showed similar and even better conversion with higher turnover frequency

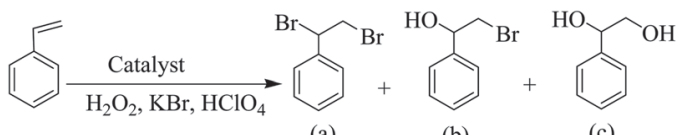

(a)

(c)

Scheme 3 Expected products upon the oxidative bromination of styrene: (a) 1,2-dibromo-1-phenylethane, (b) 2-bromo-1-phenylethane-1-ol and (c) 1-phenylethane-1,2-diol. compared to previously reported $\left[\mathrm{V}^{\mathrm{V}} \mathrm{O}(\mathrm{acac})(\mathrm{L})\right][\mathrm{Hacac}=$ acetyl acetone, $\mathrm{H}_{2} \mathrm{~L}=6,6^{\prime}$-(2-(pyridin-2-yl)ethylazanediyl)bis(methylene)bis(2,4-di-tert-butylphenol)] (ca. 99\%), ${ }^{48} \mathrm{Cs}\left(\mathrm{H}_{2} \mathrm{O}\right)$ [ $\mathrm{V}^{\mathrm{V}} \mathrm{O}_{2}\{3,5$-bis(2-hydroxyphenyl)-1-phenyl-1,2,4-triazole $\left.\}\right]$ (99\%), ${ }^{49}$ and $\left[\mathrm{K}\left(\mathrm{H}_{2} \mathrm{O}\right)_{2}\right]\left[\mathrm{VO}_{2} \mathrm{~L}\right]\left(\mathrm{H}_{2} \mathrm{~L}=\right.$ ligands derived from 4,6-diacetyl resorcinol and isonicotinoyl hydrazide, nicotinoyl hydrazide, benzoyl hydrazide or 2-furoyl hydrazide) (90-98\%), ${ }^{50}$ signifying them as efficient catalysts for the oxidative bromination of thymol. Interestingly, 3 , which contained a naphthyl substituent in the ligand backbone, showed the highest turnover frequency among the series.

Oxidative bromination of styrene. In the second case, the complexes (1-3) were also used to evaluate their efficiency towards the catalytic oxidative bromination of styrene. We again considered 2 as a representative catalyst, and the oxidative bromination of styrene was carried out at room temperature in the presence of $\mathrm{KBr}, 70 \%$ aqueous $\mathrm{HClO}_{4}$ and $30 \%$ aqueous $\mathrm{H}_{2} \mathrm{O}_{2}$ in water; this led to the formation of (a) 2-bromo1-phenylethanol and (b) 1-phenylethane-1,2-diol although the literature reports the formation of one more product, i.e., 1,2-dibromo-1-phenylethane (Scheme 3). ${ }^{22 a, 51,52}$

Consequently, the reaction was investigated by changing different parameters that may affect the rate of styrene bromination and the selectivity of different products. Thus, for $10 \mathrm{mmol}$ of styrene $(1.04 \mathrm{~g}, 10 \mathrm{mmol})$, three different amounts of catalyst $(0.0005,0.001,0.002 \mathrm{~g})$, three different amounts of $30 \%$ aqueous $\mathrm{H}_{2} \mathrm{O}_{2}(10,20$ and $30 \mathrm{mmol})$, three different amounts of $\mathrm{KBr}(10,20$ and $30 \mathrm{mmol})$ and three different amounts of $70 \%$ aqueous $\mathrm{HClO}_{4}(10,20$ and $30 \mathrm{mmol})$ were added in three equal portions to the reaction mixture as mentioned above. The details of all reaction conditions and the corresponding conversion of styrene are summarized in Table 8 (please see Fig. S5, ESI, $\dagger$ also). From the data presented in Table 8 , it is clear that the optimized reaction conditions (entry no. 8) for the maximum conversion of $10 \mathrm{mmol}(1.04 \mathrm{~g})$ of styrene include the use of $0.001 \mathrm{~g}\left(1.5 \times 10^{-3} \mathrm{M}\right)$ of catalyst, $3.39 \mathrm{~g}(30 \mathrm{mmol})$ of $30 \% \mathrm{H}_{2} \mathrm{O}_{2}, 2.38 \mathrm{~g}(20 \mathrm{mmol}) \mathrm{of} \mathrm{KBr}$, and $2.86 \mathrm{~g}(20 \mathrm{mmol})$ of $70 \% \mathrm{HClO}_{4}$. Under these conditions, the obtained conversion was $99 \%$, where the selectivity of the two products followed the order 1-phenylethane-1,2-diol (71\%) > 2-bromo-1-phenylethanol (29\%).

Table 8 Conversion of styrene $(1.04 \mathrm{~g}, 10 \mathrm{mmol})$ using 2 as a catalyst, turnover frequency, and product selectivity for $2 \mathrm{~h}$ of reaction under different reaction conditions

\begin{tabular}{|c|c|c|c|c|c|c|c|c|}
\hline \multirow[b]{2}{*}{ Entry } & \multirow[b]{2}{*}{$\mathrm{KBr}[\mathrm{g}(\mathrm{mmol})]$} & \multirow[b]{2}{*}{$\mathrm{H}_{2} \mathrm{O}_{2}[\mathrm{~g}(\mathrm{mmol})]$} & \multirow[b]{2}{*}{$\mathrm{HClO}_{4}[\mathrm{~g}(\mathrm{mmol})]$} & \multirow[b]{2}{*}{ Catalyst $[\mathrm{mg}(\mathrm{mmol})]$} & \multirow[b]{2}{*}{ Conv. $[\%]$} & \multirow[b]{2}{*}{ TOF $\left[\mathrm{h}^{-1}\right]$} & \multicolumn{2}{|c|}{ Selectivity $[\%]^{a}$} \\
\hline & & & & & & & $a$ & $b$ \\
\hline 1 & $1.19(10)$ & $1.13(10)$ & $1.43(10)$ & $0.5\left(7.5 \times 10^{-4}\right)$ & 43 & 2866 & 12 & 88 \\
\hline 2 & $1.19(10)$ & $1.13(10)$ & $1.43(10)$ & $1\left(1.5 \times 10^{-3}\right)$ & 53 & 1766 & 14 & 86 \\
\hline 3 & $1.19(10)$ & $1.13(10)$ & $1.43(10)$ & $2\left(3.0 \times 10^{-3}\right)$ & 47 & 783 & 13 & 87 \\
\hline 4 & $1.19(10)$ & $2.26(20)$ & $1.43(10)$ & $1\left(1.5 \times 10^{-3}\right)$ & 65 & 2166 & 14 & 86 \\
\hline 6 & $2.38(20)$ & $3.39(30)$ & $1.43(10)$ & $1\left(1.5 \times 10^{-3}\right)$ & 87 & 2900 & 19 & 81 \\
\hline 7 & $3.57(30)$ & $3.39(30)$ & $1.43(10)$ & $1\left(1.5 \times 10^{-3}\right)$ & 88 & 2933 & 27 & 73 \\
\hline $8^{*}$ & $2.38(20)$ & $3.39(30)$ & $2.86(20)$ & $1\left(1.5 \times 10^{-3}\right)$ & 99 & 3300 & 29 & 71 \\
\hline 9 & $2.38(20)$ & $3.39(30)$ & $4.29(30)$ & $1\left(1.5 \times 10^{-3}\right)$ & 99 & 3300 & 20 & 80 \\
\hline 10 & $2.38(20)$ & $3.39(30)$ & $4.29(30)$ & Blank & 35 & - & 24 & 76 \\
\hline
\end{tabular}

${ }^{a} a=2$-bromo-1-phenylethanol and $b=1$-phenylethane-1,2-diol. 
As observed in earlier reports for cis-[ $\left[\mathrm{VO}_{2}\right]$-complexes, ${ }^{51}$ the reaction of the complexes with $\mathrm{KBr}$ in the presence of $\mathrm{H}_{2} \mathrm{O}_{2}$ and $\mathrm{HClO}_{4}$ catalytically generated $\mathrm{HOBr}$ and/or $\mathrm{Br}^{+}, \mathrm{Br}_{2}$, and $\mathrm{Br}^{3-}$, which reacted with styrene to give bromonium ions as an intermediate. The nucleophile $\mathrm{Br}^{-}$as well as $\mathrm{H}_{2} \mathrm{O}$ may both attack the $\alpha$-carbon of the intermediate to give 1,2-dibromo-1phenylethane and 2-bromo-1-phenylethane-1-ol, respectively. The nucleophile $\mathrm{H}_{2} \mathrm{O}$ may further attack the $\alpha$-carbon of 2-bromo-1-phenylethane-1-ol to give 1-phenylethane-1,2-diol. ${ }^{52}$ All these justify the formation of 1-phenylethane-1,2-diol in the highest yield.

The other two complexes, i.e., $\mathbf{1}$ and $\mathbf{3}$ were also tested under the above-optimized reaction conditions for the maximum conversion of styrene. The results are summarized in Table S1 and Fig. S6 (ESI $\dagger$ ). It is clear from the data that the other two complexes showed comparable catalytic activities (99\%) along with high turnover frequencies; between the two products, the selectivity of 1-phenylethane-1,2-diol was always higher than that of 2-bromo-1-phenylethanol. The blank reaction afforded only $35 \%$ conversion. Thus, these complexes have potential catalytic activity.

The catalytic activity of the complexes towards the oxidative bromination of styrene also compares well with the previous results of $\left[\mathrm{V}^{\mathrm{V}} \mathrm{O}(\mathrm{OEt})(\mathrm{EtOH})(\mathrm{L})\right]\left(\mathrm{H}_{2} \mathrm{~L}=\right.$ Schiff bases derived from 2-hydroxy-1acetonaphthone or 2-hydroxy-1-naphthaldehyde and salicylhydrazide, benzoylhydrazide and anthranylhydrazide) (96-97\% conversion with $63-69 \%$ selectivity towards diol $)^{51}$ and $\left[\mathrm{Mo}^{\mathrm{VI}} \mathrm{O}_{2}(\mathrm{X}-\mathrm{Hsal}-\right.$ dahp $\left.)\left(\mathrm{H}_{2} \mathrm{O}\right)\right][(\mathrm{X}$-sal $=$ salicylaldehyde and its derivatives, dahp $=$ 1,3-diamino-2-hydroxypropane) (97-99\% conversion with $61 \%$ selectivity towards diol)], ${ }^{52}$ showing increased conversion of $99 \%$ with $75 \%$ selectivity towards the diol. Furthermore, the catalytic activity of $\mathrm{VO}(\mathrm{acac})_{2}$ was also determined under the same reaction conditions, where thymol gave $60 \pm 1 \%$ conversion, while styrene gave $c a$. $65 \%$ conversion, which was less than that observed using the complexes 1-3 reported here as catalysts.

Reactivity of complexes with $\mathrm{H}_{2} \mathrm{O}_{2}$. It has been previously reported that dioxidovanadium(v) complexes upon reaction with

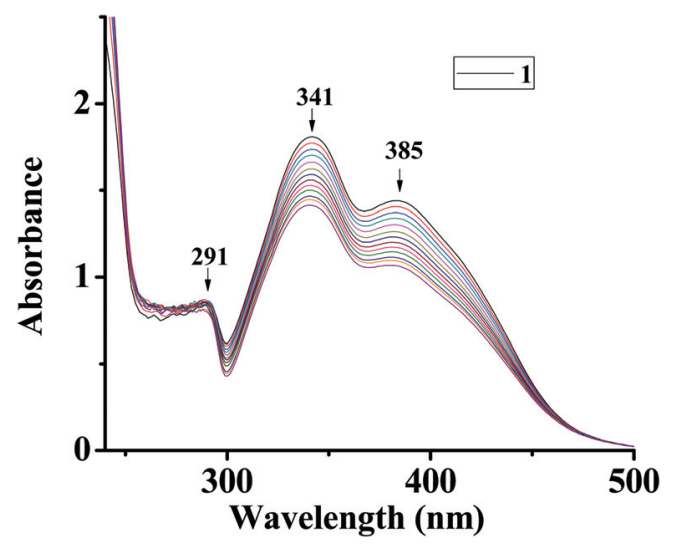

Fig. 9 Plots representing spectral changes during the titration of 1 with $\mathrm{H}_{2} \mathrm{O}_{2}$. Spectra were obtained after the successive drop-wise addition of $30 \% \mathrm{H}_{2} \mathrm{O}_{2}(0.108 \mathrm{~g}, 0.95 \mathrm{mmol})$ dissolved in $5 \mathrm{~mL}$ of $\mathrm{MeCN}$ to $25 \mathrm{~mL}$ of a $3.82 \times 10^{-5} \mathrm{M}$ solution of 1 in $\mathrm{MeCN}$
$\mathrm{H}_{2} \mathrm{O}_{2}$ provide the corresponding oxidoperoxidovanadium(v) species. ${ }^{49}$ Similar species were generated for the present study in $\mathrm{MeCN}$ and the progress of the reaction was monitored through UV-vis spectroscopy. For all the complexes, similar observations were made and as a representative, the results of $\mathbf{1}$ have been discussed here. The gradual drop-wise addition of $30 \% \mathrm{H}_{2} \mathrm{O}_{2}$ $(0.108 \mathrm{~g}, 0.95 \mathrm{mmol})$ dissolved in $5 \mathrm{~mL}$ of MeCN to $25 \mathrm{~mL}$ of a $3.82 \times 10^{-5} \mathrm{M}$ solution of 1 in MeCN led to decrease in the intensities of the 385, 341 and $291 \mathrm{~nm}$ bands (Fig. 9). This decrease occurred due to the ligand-to-metal charge transfer and intraligand transitions. These changes clearly suggested the formation of oxidoperoxidovanadium(v) species in solution. ${ }^{48-50,53}$ The reactivities of $\mathbf{2}$ and $\mathbf{3}$ are depicted in Fig. S7 and S8 (ESI $\dagger$ ), respectively.

\section{Conclusions}

Concisely, this report presented the synthesis of three new dioxidovanadium(v) complexes of tridentate binegative azohydrazone ligands $\left(\mathbf{H}_{2} \mathbf{L}^{\mathbf{1 - 3}}\right)$ and their characterization by various analytical techniques (IR, UV-vis, ${ }^{1} \mathrm{H}$ and ${ }^{13} \mathrm{C}$ NMR spectroscopy, ESI-MS and cyclic voltammetry). The molecular structures of 1-3 were established by single-crystal X-ray diffraction analysis, which revealed that vanadium was present in distorted square pyramidal geometry with $\mathrm{O}_{4} \mathrm{~N}$ coordination spheres. These complexes were evaluated for their in vitro cytotoxicity against HT-29 colon and HeLa cervical carcinoma cells. Though all the complexes were found to be cytotoxic in nature, 3 proved to be the most potent among them. The cytotoxicity of these complexes may be due to the azobenzene moiety in the ligand backbone synergizing with different substituents along with the vanadium metal. Furthermore, the catalytic potential of 1-3 was also tested for the oxidative bromination of thymol and styrene. In coherence with the antiproliferative activity, for all the cases, the percentage of conversion $(>90 \%)$ was also found to be significantly high in the presence of the catalysts with a high turnover frequency. Especially, for the oxidative bromination of thymol, the percentage of conversion and TOF were in the ranges of $98-99 \%$ and $5380-7173\left(\mathrm{~h}^{-1}\right)$, respectively. Besides, for all the catalytic reactions, 3 showed the highest TOF value, which may be due to the naphthyl substituent. Also, the brominated organic compounds synthesized through the oxidative bromination of the corresponding precursors (thymol and styrene) using 1-3 as catalysts were identified as useful starting materials for several organic transformations with biological and pharmaceutical importance. ${ }^{54}$ Again, oxidative bromination reactions using these metal complexes as catalysts can be considered as a favorable tool to replace toxic and corrosive brominating agents (i.e., $\left.\mathrm{Br}_{2}\right){ }^{54}$ Therefore, the results of the present study stimulate further insights into the mechanistic pathway of vanadium complexes in an azohydrazone ligand environment in relation to their antiproliferative and catalytic activities and also to study the correlation of the catalytic efficiency of these complexes with their biological potential. 


\section{Conflicts of interest}

There are no conflicts to declare.

\section{Acknowledgements}

R. D. thanks DBT, Govt. of India [Grant No. 6242-P112/RGCB/ PMD/DBT/RPDA/2015] and CSIR, Govt. of India [Grant No. 01(2963)/18/EMR-II] for funding this research. R. D. also thanks Prof. S. K. Chattopadhyay and Dr Indranil Banerjee for fruitful discussion related to redox and biological study.

\section{References}

1 (a) D. Rehder, Coord. Chem. Rev., 1999, 182, 297; (b) I. Correia, P. Adão, S. Roy, M. Wahba, C. Matos, M. R. Maurya, F. Marques, F. R. Pavan, C. Q. F. Leite, F. Avecilla and J. Costa Pessoa, J. Inorg. Biochem., 2014, 141, 83; (c) E. Kioseoglou, S. Petanidis, C. Gabriel and A. Salifoglou, Coord. Chem. Rev., 2015, 301-302, 87; (d) J. C. Pessoa, S. Etcheverry and D. Gambino, Coord. Chem. Rev., 2015, 301302, 24; (e) A. Chieregato, J. M. López Nieto and F. Cavani, Coord. Chem. Rev., 2015, 301-302, 3; $(f)$ J. L. Domingo and M. Gómez, Food Chem. Toxicol., 2016, 95, 137; $(g)$ D. Rehder, Metallomics, 2015, 7, 730; (h) D. Rehder, Inorg. Chim. Acta, 2017, 455, 378; (i) G. Zhang, B. L. Scott, R. Wu, L. A. P. Silks and S. K. Hanson, Inorg. Chem., 2012, 51, 7354; (j) A. E. Shilov and G. B. Shul'pin, Activation and Catalytic Reactions of Saturated Hydrocarbons in the Presence of Metal Complexes, Kluwer Academic Publishers, New York, 2002; $(k)$ G. B. Shul'pin, in Comprehensive Inorganic Chemistry II, ed. J. Reedijk, K. Poeppelmeier and L. Casella, Elsevier, Amsterdam, 2013, vol. 6, p. 79; (l) A. Pokutsa, Y. Kubaj, A. Zaborovskyi, D. Maksym, T. Paczesniak, B. Mysliwiec, E. Bidzinska, J. Muzart and A. Sobkowiak, Mol. Catal., 2017, 434, 194; (m) D. C. Crans, J. J. Smee, E. Gaidamauskas and L. Yang, Chem. Rev., 2004, 104, 849; (n) K. H. Thompson, J. H. McNeill and C. Orvig, Chem. Rev., 1999, 99, 2561; (o) T. Jakusch and T. Kiss, Coord. Chem. Rev., 2017, 351, 118; (p) D. Gambino, Coord. Chem. Rev., 2011, 255, 2193; $(q)$ M. Selman, et al., Mol. Ther., 2018, 26, 56; (r) G. R. Willsky, L.-H. Chi, Z. Hu and D. C. Crans, Coord. Chem. Rev., 2011, 255, 2258.

2 E. G. Ferrer, A. Bosch, O. Yantorno and E. J. Baran, Bioorg. Med. Chem., 2008, 16, 3878.

3 (a) I. G. Macara, Trends Biochem. Sci., 1980, 5, 92; (b) H. Vilter, Phytochemistry, 1984, 23, 1387; (c) E. de Boer and R. Wever, J. Biol. Chem., 1988, 263, 12326; (d) B. Mukherjee, B. Patra, S. Mahapatra, P. Banerjee, A. Tiwari and M. Chatterjee, Toxicol. Lett., 2004, 150, 135; (e) D. Rehder, Bioinorganic Vanadium Chemistry, John Wiley \& Sons, Chichester, UK, 2008.

4 (a) M. N. Isupov, A. R. Dalby, A. A. Brindley, Y. Izumi, T. Tanabe, G. N. Murshudov and J. A. Littlechild, J. Mol. Biol., 2000, 299, 1035; (b) J. Littlechild and E. Garcia-Rodriguez, Coord. Chem. Rev., 2003, 237, 65; (c) M. Almeida, S. Filipe, M. Humanes, M. F. Maia, R. Melo, N. Severino, J. A. L. da Silva, J. J. R. Fraústo da Silva and R. Wever, Phytochemistry, 2001,
57, 633; (d) R. Wever and W. Hemrika, in Handbook of Metalloproteins, ed. A. Messerschmidt, R. Hubert, T. Poulos and K. Wieghardt, John Wiley \& Sons, Ltd, Chichester, 2001, vol. 2, p. 1417; (e) C. Leblanc, H. Vilter, J. B. Fournier, L. Delage, P. Potin, E. Rebuffet, G. Michel, P. L. Solari, M. C. Feiters and M. Czjzek, Coord. Chem. Rev., 2015, 301-302, 134; $(f)$ D. Wischang, O. Brücher and J. Hartung, Coord. Chem. Rev., 2011, 255, 2204; (g) V. Conte, A. Coletti, B. Floris, G. Licini and C. Zonta, Coord. Chem. Rev., 2011, 255, 2165; (h) M. Sutradhar, L. M. D. R. S. Martins, M. F. C. Guedes da Silva and A. J. L. Pombeiro, Coord. Chem. Rev., 2015, 301-302, 200.

5 (a) M. Weyand, H. J. Hecht, M. Kiess, M. F. Liaud, H. Vilter and D. Schomburg, J. Mol. Biol., 1999, 293, 595; (b) W. Plass, Angew. Chem., Int. Ed., 1999, 38, 909; (c) R. R. Eady, Coord. Chem. Rev., 2003, 237, 23; (d) J. N. Carter-Franklin, J. D. Parrish, R. A. Tschirret-Guth, R. D. Little and A. Butler, J. Am. Chem. Soc., 2003, 125, 3688; (e) J. Costa Pessoa, E. Garribba, M. F. A. Santos and T. Santos-Silva, Coord. Chem. Rev., 2015, 301-302, 49.

6 (a) H. Kneifel and E. Bayer, J. Am. Chem. Soc., 1986, 108, 3075; (b) R. L. Robson, R. R. Eady, T. H. Richardson, R. W. Miller, M. Hawkins and J. R. Postgate, Nature, 1986, 322, 388; (c) H. Vilter, Photochemistry, 1984, 23, 1387; (d) E. de Boer, Y. van Kooky, M. G. M. Tromp, H. Plat and R. Waver, Biochim. Biophys. Acta, 1986, 869, 48; (e) A. Butler and J. V. Walker, Chem. Rev., 1993, 93, 1937.

7 (a) H. Sakurai, K. Tsuchiya, M. Nukatsuka, J. Kawada, S. Ishikawa, H. Yoshida and M. Komatsu, J. Clin. Biochem. Nutr., 1990, 8, 193; (b) D. C. Crans, M. Mahroof-Tahir and A. D. Keramidas, Mol. Cell. Biochem., 1995, 153, 17; (c) K. H. Thompson and C. Orvig, Coord. Chem. Rev., 2001, 219-221, 1033; (d) H. Sakurai, Y. Kojima, Y. Yoshikawa, K. Kawabe and H. Yasui, Coord. Chem. Rev., 2002, 226, 187; (e) A. M. Evangelou, Crit. Rev. Oncol. Hematol., 2002, 42, 249; (f) H. Sakurai, Y. Yoshikawa and H. Yasui, Chem. Soc. Rev., 2008, 37, 2383; $(g)$ T. Kiss, T. Jakusch, D. Hollender, É. A. Enyedy and L. Horváth, J. Inorg. Biochem., 2009, 103, 527; (h) K. H. Thompson, J. Lichter, C. LeBel, M. C. Scaife, J. H. McNeill and C. Orvig, J. Inorg. Biochem., 2009, 103, 554; (i) A. Bishayee, A. Waghray, M. A. Patel and M. Chatterjee, Cancer Lett., 2010, 294, 1; $(j)$ Y. Yoshikawa, H. Sakurai, D. C. Crans, G. Micera and E. Garribba, Dalton Trans., 2014, 43, 6965; (k) A. Levina, A. I. McLeod, S. J. Gasparini, A. Nguyen, W. G. M. De Silva, J. B. Aitken, H. H. Harris, C. Glover, B. Johannessen and P. A. Lay, Inorg. Chem., 2015, 54, 7753; (l) L. R. Morgan, B. S. Jursic, C. L. Hooper, D. M. Neumann, K. Thangaraj and B. LeBlanc, Bioorg. Med. Chem. Lett., 2002, 12, 3407; (m) P. Dandawate, E. Khan, S. Padhye, H. Gaba, S. Sinha, J. Deshpande, S. K. Venkateswara, M. Khetmalas, A. Ahmad and F. H. Sarkar, Bioorg. Med. Chem. Lett., 2012, 22, 3104; (n) W. Y. Liu, H. Y. Li, B. X. Zhao, D. S. Shin, S. Lian and J. Y. Miao, Carbohydr. Res., 2009, 344, 1270; (o) S. Thomas, G.-G. Jose Antonio, D. Quoc-Tuan, B. Philippe and L. Stefan, Curr. Med. Chem., 2016, 23, 2874; (p) P. P. Hazari, A. K. Pandey, 
S. Chaturvedi, A. K. Tiwari, S. Chandna, B. S. Dwarakanath and A. K. Mishra, Chem. Biol. Drug Des., 2012, 79, 223; (q) S. Kowalski, I. Inkielewicz-Stepniak, S. Hac, D. Wyrzykowski and A. Zauszkiewicz-Pawlak, Oncotarget, 2017, 8, 60324; (r) R. K. Narla, Y. Dong, O. J. D'Cruz, C. Navara and F. M. Uckun, Clin. Cancer Res., 2000, 6, 1546.

8 (a) V. Gomathi Sankareswari, D. Vinod, A. Mahalakshmi, M. Alamelu, G. Kumaresan, R. Ramaraj and S. Rajagopal, Dalton Trans., 2014, 43, 3260; (b) P. Koepf-Maier and H. Koepf, Chem. Rev., 1987, 87, 1137; (c) B. Gleeson, J. Claffey, M. Hogan, H. Müller-Bunz, D. Wallis and M. Tacke, J. Organomet. Chem., 2009, 694, 1369.

9 (a) R. K. Narla, Y. Dong, D. Klis and F. M. Uckun, Clin. Cancer Res., 2001, 7, 1094; (b) R. K. Narla, C.-L. Chen, Y. Dong and F. M. Uckun, Clin. Cancer Res., 2001, 7, 2124; (c) O. J. D'Cruz and F. M. Uckun, Expert Opin. Invest. Drugs, 2002, 11, 1829.

10 (a) S. P. Dash, A. K. Panda, S. Pasayat, R. Dinda, A. Biswas, E. R. T. Tiekink, Y. P. Patil, M. Nethaji, W. Kaminsky, S. Mukhopadhyay and S. K. Bhutia, Dalton Trans., 2014, 43, 10139; (b) S. P. Dash, A. K. Panda, S. Pasayat, R. Dinda, A. Biswas, E. R. T. Tiekink, S. Mukhopadhyay, S. K. Bhutia, W. Kaminsky and E. Sinn, RSC Adv., 2015, 5, 51852; (c) S. P. Dash, A. K. Panda, S. Pasayat, S. Majumder, A. Biswas, W. Kaminsky, S. Mukhopadhyay, S. K. Bhutia and R. Dinda, J. Inorg. Biochem., 2015, 144, 1; (d) Saswati, P. Adão, S. Majumder, S. P. Dash, S. Roy, M. L. Kuznetsov, J. Costa Pessoa, C. S. B. Gomes, M. R. Hardikar, E. R. T. Tiekink and R. Dinda, Dalton Trans., 2018, 47, 11358; (e) S. Roy, M. Böhme, S. P. Dash, M. Mohanty, A. Buchholz, W. Plass, S. Majumder, S. Kulanthaivel, I. Banerjee, H. Reuter, W. Kaminsky and R. Dinda, Inorg. Chem., 2018, 57, 5767.

11 (a) L. Savini, L. Chiasserini, V. Travagli, C. Pellerano, E. Novellino, S. Cosentino and M. B. Pisano, Eur. J. Med. Chem., 2004, 39, 113; (b) Z. Cui, X. Yang, Y. Shi, H. Uzawa, J. Cui, H. Dohi and Y. Nishida, Bioorg. Med. Chem. Lett., 2011, 21, 7193; (c) A. C. Cunha, J. M. Figueiredo, J. L. M. Tributino, A. L. P. Miranda, H. C. Castro, R. B. Zingali, C. A. M. Fraga, M. C. B. V. Souza, V. F. Ferreira and E. Barreiro, Bioorg. Med. Chem., 2003, 11, 2051; (d) J. Easmon, G. Pürstinger, K.-S. Thies, G. Heinisch and J. Hofmann, J. Med. Chem., 2006, 49, 6343; (e) T. B. Chaston, R. N. Watts, J. Yuan and D. R. Richardson, Clin. Cancer Res., 2004, 10, 7365; $(f)$ G. R. Braslawsky, M. A. Edson, W. Pearce, T. Kaneko and R. S. Greenfield, Cancer Res., 1990, 50, 6608; (g) G. Darnell and D. R. Richardson, Blood, 1999, 94, 781; (h) C. Fan, H. Su, J. Zhao, B. Zhao, S. Zhang and J. Miao, Eur. J. Med. Chem., 2010, 45, 1438; (i) Y. Xia, C.-D. Fan, B.-X. Zhao, J. Zhao, D.-S. Shin and J.-Y. Miao, Eur. J. Med. Chem., 2008, 43, 2347; $(j)$ K. Effenberger, S. Breyer and R. Schobert, Eur. J. Med. Chem., 2010, 45, 1947; ( $k$ ) G. S. Hassan, H. H. Kadry, S. M. Abou-Seri, M. M. Ali and A. E. E.-D. Mahmoud, Bioorg. Med. Chem., 2011, 19, 6808; (l) F.-F. Tian, J.-H. Li, F.-L. Jiang, X.-L. Han, C. Xiang, Y.-S. Ge, L.-L. Li and Y. Liu, RSC Adv., 2012, 2, 501; $(m)$ D. R. Richardson, Antimicrob. Agents Chemother., 1997, 41, 2061.
12 (a) G. S. Hartley, Nature, 1937, 140, 281; (b) H. Asanuma, X. Liang, T. Yoshida and M. Komiyama, ChemBioChem, 2001, 2, 39.

13 (a) P. Sathyadevi, P. Krishnamoorthy, R. R. Butorac, A. H. Cowley, N. S. P. Bhuvanesh and N. Dharmaraj, Dalton Trans., 2011, 40, 9690; (b) E. Ramachandran, D. S. Raja, J. L. Mike, T. R. Wagner, M. Zeller and K. Natarajan, RSC Adv., 2012, 2, 8515.

14 J. A. L. da Silva, J. J. R. F. da Silva and A. J. L. Pombeiro, Coord. Chem. Rev., 2011, 255, 2232.

15 (a) M. R. Maurya, A. K. Chandrakar and S. Chand, J. Mol. Catal. A: Chem., 2007, 263, 227; (b) S. Barroso, P. Adão, F. Madeira, M. T. Duarte, J. C. Pessoa and A. M. Martins, Inorg. Chem., 2010, 49, 7452.

16 M. R. Maurya, C. Haldar, A. A. Khan, A. Azam, A. Salahuddin, A. Kumar and J. Costa Pessoa, Eur. J. Inorg. Chem., 2012, 2560.

17 B. N. Wigington, M. L. Drummond, T. R. Cundari, D. L. Thorn, S. K. Hanson and S. L. Scott, Chem. - Eur. J., 2012, 18, 14981.

18 M. R. Maurya and N. Kumar, J. Mol. Catal. A: Chem., 2014, 383-384, 172.

19 M. R. Maurya, A. Kumar and J. Costa Pessoa, Coord. Chem. Rev., 2011, 255, 2315.

20 M. U. Anwar, K. V. Shuvaev, L. N. Dawe and L. K. Thompson, Inorg. Chem., 2011, 50, 12141.

21 (a) P. Adão, J. Costa Pessoa, R. T. Henriques, M. L. Kuznetsov, F. Avecilla, M. R. Maurya, U. Kumar and I. Correia, Inorg. Chem., 2009, 48, 3542; (b) S. M. de Lima, J. A. Gómez, V. P. Barros, G. d. S. Vertuan, M. d. D. Assis, C. F. d. O. Graeff and G. J.-F. Demets, Polyhedron, 2010, 29, 3008; (c) V. Conte and B. Floris, Dalton Trans., 2011, 40, 1419.

22 (a) S. P. Dash, A. K. Panda, S. Dhaka, S. Pasayat, A. Biswas, M. R. Maurya, P. K. Majhi, A. Crochet and R. Dinda, Dalton Trans., 2016, 45, 18292; (b) S. P. Dash, S. Pasayat, S. Bhakat, S. Roy, R. Dinda, E. R. T. Tiekink, S. Mukhopadhyay, S. K. Bhutia, M. R. Hardikar, B. N. Joshi, Y. P. Patil and M. Nethaji, Inorg. Chem., 2013, 52, 14096.

23 (a) D. Braga, F. Grepioni and G. R. Desiraju, Chem. Rev., 1998, 98, 1375; (b) D. Braga and F. Grepioni, Coord. Chem. Rev., 1999, 183, 19; (c) D. Braga and F. Grepioni, Acc. Chem. Res., 2000, 33, 601.

24 R. A. Rowe and M. M. Jones, Inorg. Synth., 1957, 5, 113.

25 A. A. Khandar and Z. Rezvani, Polyhedron, 1998, 18, 129.

26 O. V. Dolomanov, L. J. Bourhis, R. J. Gildea, J. A. K. Howard and H. Puschmann, J. Appl. Crystallogr., 2009, 42, 339.

27 G. M. Sheldrick, Acta Crystallogr., Sect. A: Found. Adv., 2015, $71,3$.

28 G. M. Sheldrick, Acta Crystallogr., Sect. C: Struct. Chem., 2015, 71, 3.

29 A. L. Spek, Acta Crystallogr., Sect. D: Biol. Crystallogr., 2009, 65, 148.

30 L. Serpe, M. G. Catalano, R. Cavalli, E. Ugazio, O. Bosco, R. Canaparo, E. Muntoni, R. Frairia, M. R. Gasco, M. Eandi and G. P. Zara, Eur. J. Pharm. Biopharm., 2004, 58, 673.

31 S. Mukhopadhyay, P. K. Panda, B. Behera, C. K. Das, M. K. Hassan, D. N. Das, N. Sinha, A. Bissoyi, 
K. Pramanik, T. K. Maiti and S. K. Bhutia, Food Chem. Toxicol., 2014, 64, 369.

32 (a) R. Dinda, P. Sengupta, S. Ghosh and T. C. W. Mak, Inorg. Chem., 2002, 41, 1684; (b) R. Dinda, P. Sengupta, M. Sutradhar, T. C. W. Mak and S. Ghosh, Inorg. Chem., 2008, 47, 5634; (c) S. Das, G. P. Muthukumaragopal, S. Pal and S. Pal, New J. Chem., 2003, 27, 1102.

33 (a) R. Dinda, P. K. Majhi, P. Sengupta, S. Pasayat, S. Ghosh, L. R. Falvello and T. C. W. Mak, Polyhedron, 2010, 29, 248; (b) A. Hazra, S. Gupta, S. Roy, T. N. Mandal, K. Das, S. Konar, A. Jana, S. Ray, R. J. Butcher and S. K. Kar, Polyhedron, 2011, 30, 187.

34 S. P. Dash, S. Pasayat, Saswati, H. R. Dash, S. Das, R. J. Butcher and R. Dinda, Polyhedron, 2012, 31, 524.

35 A. W. Addison, T. N. Rao, J. Reedijk, J. van Rijn and G. C. Verschoor, Dalton Trans., 1984, 1349.

36 (a) H. Glas, E. Herdtweck, G. R. J. Artus and W. R. Thiel, Inorg. Chem., 1998, 37, 3644; (b) Y. Sun, M. Melchior, D. A. Summers, R. C. Thompson, S. J. Rettig and C. Orvig, Inorg. Chem., 1998, 37, 3119.

37 (a) A. M. Ramadan, J. Inorg. Biochem., 1997, 65, 183; (b) P. G. Avaji, C. H. Vinod Kumar, S. A. Patil, K. N. Shivananda and C. Nagaraju, Eur. J. Med. Chem., 2009, 44, 3552.

38 (a) L. Reytman, O. Braitbard and E. Y. Tshuva, Dalton Trans., 2012, 41, 5241, and references therein; (b) A. Stockert, D. Kinder, M. Christ, K. Amend, A. Aulthouse and J. Austin, Pharmacol. Ther., 2014, 2, 6; (c) A. D. Lewis, L. M. Forrester, J. D. Hayes, C. J. Wareing, J. Carmichael, A. L. Harris, M. Mooghen and C. R. Wolf, Br. J. Cancer, 1989, 60, 327; (d) K. Takara, T. Sakaeda, T. Yagami, H. Kobayashi, N. Ohmoto, M. Horinouchi, K. Nishiguchi and K. Okumura, Biol. Pharm. Bull., 2002, 25, 771.

39 N. A. Lewis, F. Liu, L. Seymour, A. Magnusen, T. R. Erves, J. F. Arca, F. A. Beckford, R. Venkatraman, A. GonzálezSarrías, F. R. Fronczek, D. G. VanDerveer, N. P. Seeram, A. Liu, W. L. Jarrett and A. A. Holder, Eur. J. Inorg. Chem., 2012, 664 .

40 S. Pasayat, S. P. Dash, S. Majumder, R. Dinda, E. Sinn, H. Stoeckli-Evans, S. Mukhopadhyay, S. K. Bhutia and P. Mitra, Polyhedron, 2014, 80, 198.

41 M. A. Jordan and L. Wilson, Curr. Opin. Cell Biol., 1998, $10,123$.
42 Z. H. Siddik, Oncogene, 2002, 22, 7265.

43 C. Temperini, C. D. Bugno, F. Animati, G. Ughetto, L. Messori and P. Orioli, Nucleic Acids Res., 2003, 31, 1464.

44 M. C. Wani, H. L. Taylor, M. E. Wall, P. Coggon and A. T. McPhail, J. Am. Chem. Soc., 1971, 93, 2325.

45 (a) X. D. Feng, X. X. Zhang, Z. N. Wang, J. Song, Y. H. Xing and F. Y. Bai, New J. Chem., 2016, 40, 1222; (b) F. Natalio, R. André, A. F. Hartog, B. Stoll, K. P. Jochum, R. Wever and W. Tremel, Nat. Nanotechnol., 2012, 7, 530; (c) Y.-Z. Cao, H.-Y. Zhao, F.-Y. Bai, Y.-H. Xing, D.-M. Wei, S.-Y. Niu and Z. Shi, Inorg. Chim. Acta, 2011, 368, 223; (d) H.-Y. Zhao, Y.-H. Xing, Y.-Z. Cao, Z.-P. Li, D.-M. Wei, X.-Q. Zeng and M.-F. Ge, J. Mol. Struct., 2009, 938, 54.

46 (a) H.-Y. Zhao, Y.-H. Zhang, Y.-H. Xing, Z.-P. Li, Y.-Z. Cao, M.-F. Ge, X.-Q. Zeng and S.-Y. Niu, Inorg. Chim. Acta, 2009, 362, 4110; (b) D. X. Ren, N. Xing, H. Shan, C. Chen, Y. Z. Cao and Y. H. Xing, Dalton Trans., 2013, 42, 5379.

47 (a) A. G. J. Ligtenbarg, R. Hage and B. L. Feringa, Coord. Chem. Rev., 2003, 237, 89; (b) G. J. Colpas, B. J. Hamstra, J. W. Kampf and V. L. Pecoraro, J. Am. Chem. Soc., 1996, 118, 3469.

48 M. R. Maurya, B. Uprety, F. Avecilla, P. Adão and J. Costa Pessoa, Dalton Trans., 2015, 44, 17736.

49 M. R. Maurya, B. Sarkar, F. Avecilla, S. Tariq, A. Azam and I. Correia, Eur. J. Inorg. Chem., 2016, 1430.

50 M. R. Maurya, N. Jangra, F. Avecilla and I. Correia, Eur. J. Inorg. Chem., 2019, 314.

51 M. R. Maurya, C. Haldar, A. Kumar, M. L. Kuznetsov, F. Avecilla and J. Costa Pessoa, Dalton Trans., 2013, 42, 11941.

52 M. R. Maurya, S. Dhaka and F. Avecilla, Polyhedron, 2014, 67, 145.

53 (a) S. Majumder, S. Pasayat, S. Roy, S. P. Dash, S. Dhaka, M. R. Maurya, M. Reichelt, H. Reuter, K. Brzezinski and R. Dinda, Inorg. Chim. Acta, 2018, 469, 366; (b) S. Roy, Saswati, S. Lima, S. Dhaka, M. R. Maurya, R. Acharyya, C. Eagle and R. Dinda, Inorg. Chim. Acta, 2018, 474, 134; (c) S. Pasayat, M. Böhme, S. Dhaka, S. P. Dash, S. Majumder, M. R. Maurya, W. Plass, W. Kaminsky and R. Dinda, Eur. J. Inorg. Chem., 2016, 1604.

54 F. Sabuzi, G. Pomarico, B. Floris, F. Valentini, P. Galloni and V. Conte, Coord. Chem. Rev., 2019, 385, 100. 